\title{
Nerve growth factor regulates tyrosine hydroxylase gene transcription through a nucleoprotein complex that contains c-Fos
}

\author{
Elena Gizang-Ginsberg and Edward B. Ziff ${ }^{1}$ \\ Department of Biochemistry and Kaplan Cancer Center, New York University Medical Center, New York, New York 10016 \\ USA
}

\begin{abstract}
We have studied nerve growth factor (NGF) regulation of the expression of the tyrosine hydroxylase (TH) gene in PC12 cells. The TH gene encodes the initial and rate-limiting enzyme of the catecholamine biosynthetic pathway. We show that the TH gene is transiently transcriptionally induced by a mechanism reliant on new protein synthesis during 1-2 hr of NGF stimulation, a time following the induction of the c-fos gene at 15 min post-NGF treatment. A potential regulatory sequence located within the TH gene promoter, the TH-FSE, shares homology to a known regulatory element, the fat-specific element (FSE), which is found upstream from genes activated during adipocyte differentiation and binds the Fos-Jun transcription factor complex. We show that the TH-FSE DNA sequence elevates the basal level of transcription from the rat TH promoter and is required for NGF inducibility. This DNA element binds authentic Fos-Jun products produced by in vitro translation. We demonstrate further that the TH-FSE can bind proteins present in PC12 nuclear extracts in a sequence-specific manner. The DNA/nucleoprotein complex that forms increases in abundance during NGF stimulation and reaches a maximum level at $4 \mathrm{hr}$ of treatment. Antibody inhibition studies utilizing an anti-Fos antibody indicate that Fos and/or Fos-related antigen(s) associate with the TH-FSE and suggest that the Fos protein family contributes to the regulation of TH in vivo. These results support a model in which NGF-induced immediate early genes, including c-Fos, contribute to the regulation of delayed early genes such as $\mathrm{TH}$ and thereby control neuronal differentiation.
\end{abstract}

[Key Words: Transcriptional regulation; DNA-protein nucleoprotein complexes; c-Fos; growth factors]

Received January 9, 1990; revised version accepted February 8, 1990.

During neuronal development, the peptide hormone nerve growth factor (NGF) is required for the differentiation and maintenance of sympathetic and sensory neurons of the peripheral nervous system (Levi-Montalcini 1966; Levi-Montalcini and Angeletti 1968). For example, NGF directs the differentiation of precursor cells into sympathetic adrenergic neurons following cell migration from the sympathoadrenal portion of the neural crest to specific target regions of the embryonic nervous system (Landis and Patterson 1981; Doupe et al. 1985; Anderson and Axel 1986). NGF can also serve as a mitogen, as described for primary chromaffin cell cultures in vitro (Lillien and Claude 1985). Although the biological effects of NGF have been well established, the mechanism of its action is currently unknown. An in vitro model used extensively to study the effects and mechanism of action of NGF is the rat pheochromocytoma cell line, PC12 (Greene and Tischler 1976; 1982). In the undifferentiated state, $\mathrm{PC} 12$ cells resemble their normal counterparts, neural crest-derived precursor cells. Upon NGF stimulation, PC12 cells undergo a diverse set of molecular and gross morphological changes

${ }^{1}$ Corresponding author. and express many metabolic processes similar to sympathetic neurons, including extension of neurites, which are visible by $1-2$ days following NGF exposure. The growth-factor-induced differentiation of PC12 cells appears to reflect developmental properties of their normal counterparts because similar morphological changes have been observed when normal neonatal rat adrenal medullary cells are exposed to NGF /Unsicker et al. 1978; Aloe and Levi-Montalcini 1979; Anderson and Axel 1986).

Previous studies in our laboratory (Leonard et al. 1987) utilizing differential screening of cDNA libraries from PC1 2 cells have identified several genes regulated by NGF. These studies suggest that NGF-induced differentiation is accompanied by the activation of various classes of genes whose onset of transcription occurs at different times following NGF stimulation. The first class includes the immediate early genes or early response genes. In PC12 and other cells, transcription of this class is induced rapidly (within $5-10 \mathrm{~min}$ ) and transiently upon stimulation by growth factors when cells re-enter the cell cycle /Cochran et al. 1983; Greenberg and Ziff 1984; Lau and Nathans 1985, 1987; Lin et al. 1987; Sukhatme et al. 1987; Almendral et al. 1988) or 
differentiate /Greenberg et al. 1985; Cho et al. 1989; Milbrandt 1987, 1988; Bartel et al. 1989; Tirone and Shooter 1989). Members of this class include several putative transcription factors whose products may mediate the growth factor response of the cell. In PCl2 cells, these include c-fos /Curran and Morgan 1985, 1986; Greenberg et al. 1985; Kruijer et al. 1985; Milbrandt 1986), the cellular proto-oncogene counterpart of the transforming gene of the FBJ and FBR osteosarcoma viruses (Curran and Teich 1982; Curran et al. 1982; Curran and Verma 1984); c-jun (Bartel et al. 1989), the cellular proto-oncogene counterpart of the transforming gene of avian sarcoma virus 17 (Maki et al. 1987); NGFI$A$ and related zif/268 and egr-1 genes encoding products that contain a zinc-finger DNA-binding domain (Milbrandt 1987; Sukhatme et al. 1987, 1988; Christy et al. 1988); and NGFI-B (nur77), an early response gene that has sequence similarity to the glucocorticoid receptor (Hazel et al. 1988; Milbrandt 1988; Watson and Milbrandt 1989|. A second class of genes, the delayed early genes, is transiently activated within $1-2 \mathrm{hr}$ of NGF stimulation and includes genes whose products may be important for early events during the transition from the chromaffin to the neuronal cell state. This class includes the tyrosine hydroxylase (TH) gene (Leonard et al. 1987). A third class includes the peripherin gene, which encodes a neuron-specific intermediate filament protein (Portier et al. 1984; Leonard et al. 1987, 1988; Parysek et al. 1988; Thompson and Ziff 1989). Peripherin is representative of a class of "late" genes whose transcription is induced $\sim 18 \mathrm{hr}$ post-NGF, a time coinciding with the onset of neurite extension.

Given the order of activation of NGF-inducible genes, we hypothesized that members of the immediate early class, specifically c-fos, may control genes such as the TH gene, which are subsequently transcriptionally activated during differentiation. Recent studies have demonstrated that the products of $c$-fos and members of the c-jun gene family (Rauscher et al. 1988b; Ryder et al. 1988, 1989; Sassone-Corsi et al. 1988a; Hirai et al. 1989) can form heterodimeric complexes capable of binding DNA, specifically at AP-1 sites $\left(5^{\prime}\right.$-ATGACTCAT- $3^{\prime}$; phorbol-ester-responsive sequence) with high affinity (Halazonetis et al. 1988; Kouzarides and Ziff 1988; Nakabeppu et al. 1988; Rauscher et al. 1988a,c; SassoneCorsi et al. 1988c; for review, see Curran and Franza 1988). More direct evidence of the role of c-Fos as a trans-acting transcription factor has recently been demonstrated for the adipocyte gene, aP2 (Distel et al. 1987; Franza et al. 1988; Rauscher et al. 1988c), the transin gene (Kerr et al. 1988), the mouse $\alpha 1$ (III) collagen gene (Setoyama et al. 1986), the collagenase gene (Schonthal et al. 1988), several viral promoters (Franza et al. 1988), and its own promoter (Sassone-Corsi et al. 1988b; Konig et al. 1989).

The TH gene encodes TH, the enzyme that catalyzes the rate-limiting step in the catecholamine biosynthetic pathway, the conversion of tyrosine to 3,4-dihydroxyphenylalanine (DOPA), a precursor to various neurotransmitters. TH is expressed in catecholaminergic neu- rons of the peripheral and central nervous system and in chromaffin cells of the adrenal medulla that originate from the neural crest. Both in vivo and in vitro studies have demonstrated that $\mathrm{TH}$ enzyme activity can be modulated by various extracellular effector molecules that include stress (Thoenen 1970) agents that deplete catecholamine stores (i.e., reserpine; Mueller et al. 1969), glucocorticoids (Hanbauer et al. 1975; Lucas and Thoenen 1977; Edgar and Thoenen 1978; Tank et al. 1986), cAMP (Kumakara et al. 1979; Acheson et al. 1984; Tank et al. 1986), insulin (Schubert et al. 1980), epidermal growth factor (EGF; Goodman et al. 1980), as well as NGF (Goodman and Herschman 1978; Rohrer et al. 1978; Hatanaka 1981; Naujoks et al. 1982; Acheson et al. 1984). Several mechanisms have been proposed for regulating $\mathrm{TH}$ activity, including changes in the rate of enzyme synthesis (Hanbauer 1975; Goodman and Herschman 1978; Schubert et al. 1980; Tank et al. 1986), post-translational modifications of preexisting enzyme molecules (i.e., phosphorylation; Vulliet et al. 1980; Campbell et al. 1986), and other post-transcriptional events (Rohrer et al. 1978; Acheson et al. 1984). More recently, it has been demonstrated that the $\mathrm{TH}$ gene is transcriptionally regulated in response to EGF (Lewis and Chikaraishi 1987), glucocorticoids (Tank et al. 1986; Harrington et al. 1987; Lewis et al. 1987), and cAMP (Tank et al. 1986; Lewis et al. 1987). The exact molecular mechanism(s) by which NGF and other transmembrane signaling agents control the $\mathrm{TH}$ gene is currently unknown.

In this communication, we have examined the regulation of the TH gene during NGF-induced PC12 cell differentiation. Our results demonstrate that in response to NGF, the TH gene is transiently transcriptionally induced with delayed early kinetics. The $5^{\prime}$ regulatory region of the rat $\mathrm{TH}$ gene contains a potential regulatory sequence, the TH-FSE, which shows extensive homology to the fat-specific element (FSE) present in genes induced during adipocyte differentiation (Distel et al. 1987; Franza et al. 1988; Rauscher et al. 1988c), and binds inducible factors, specifically c-Fos. We present evidence that the TH-FSE forms a sequence-specific complex with proteins induced in vivo in response to NGF and contributes to the transcriptional induction of the TH gene by NGF. Changes in the DNA-protein complex that forms at the TH-FSE suggest that the element may provide both positive and negative control of $\mathrm{TH}$ transcriptional activity. Taken together, our evidence suggests a growth-factor-induced cascade of gene activity in which an inducible transcription factor protein, c-Fos, functions in the regulation of a gene essential to growth-factor-stimulated differentiation.

\section{Results}

NGF induction of the TH gene is transcriptionally regulated and reliant on protein synthesis

Previous studies have demonstrated that $\mathrm{TH}$ activity is elevated following NGF treatment in various rat clonal pheochromocytoma cell lines /Goodman and 
Herschman 1978; Hatanaka 1981), primary adrenal chromaffin cell cultures (Acheson et al. 1984), and rat superior cervical ganglia organ cultures (Rohrer et al. 1978). Initial analysis of TH mRNA levels during NGF induction of $\mathrm{PC} 12$ cell differentiation revealed a slight increase (approximately twofold) in message levels by 4 hr of NGF treatment, which was followed by a decrease to initial basal levels in mRNA appearance (Leonard et al. 1987). To determine whether this control is at the transcriptional level, we utilized the nuclear run-on transcription assay (Greenberg and Ziff 1984) to measure the transcription rate of $\mathrm{TH}$ and other genes during the 8 $\mathrm{hr}$ following NGF induction of PCl2 cells. Figure 1A shows that the $\mathrm{TH}$ gene is transcriptionally induced at a maximum rate $1 \mathrm{hr}$ after NGF treatment. This response follows the transcriptional induction of the c-fos and $\beta$ actin genes at 30 min post-NGF treatment /Greenberg et al. 1985, 1986). As expected, the late response gene, peripherin (Thompson and Ziff 1989), and other genes unresponsive to NGF during this time period (Greenberg et al. 1985, 1986; Leonard et al. 1987) were not induced. The 10b gene, a second NGF-inducible delayed early gene of unknown function (Leonard et al. 1987; E. Gizang-Ginsberg and E.B. Ziff, unpubl.) is induced with kinetics similar to TH (Fig. 1B).

We then asked whether the induction of the TH gene by NGF relied on new protein synthesis. PC12 cells were treated with either the protein synthesis inhibitor cycloheximide or anisomycin (Lewis and Matthews 1980), with both inhibitors, or with neither inhibitor be-

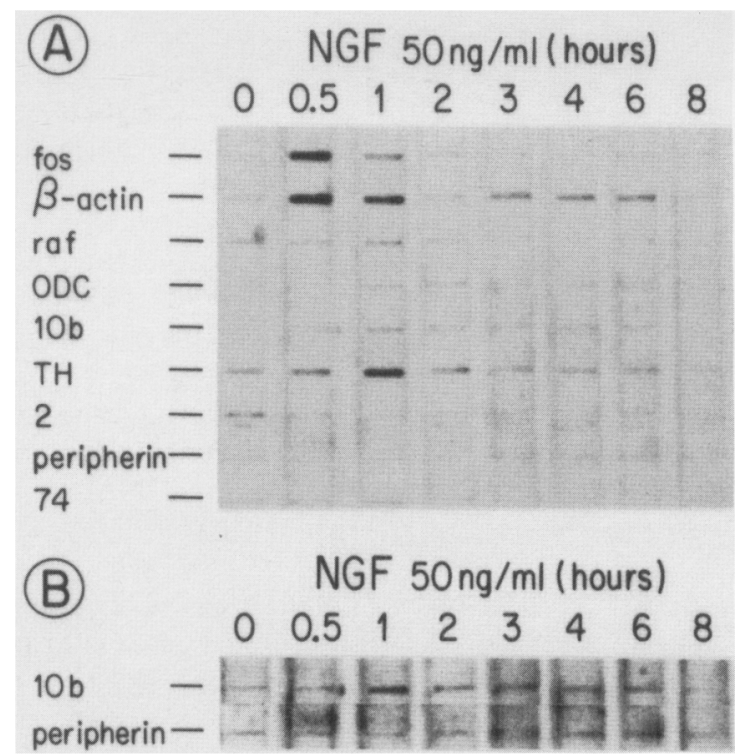

Figure 1. Kinetics of gene activation following NGF stimulation of $\mathrm{PC} 12$ cells. Nuclear run-on transcription assay was performed as described previously (Greenberg et al. 1985) by using ${ }^{32} \mathrm{P}$-labeled RNA transcripts obtained from nuclei isolated from untreated and NGF-treated PC12 cells. The radiolabeled transcripts were hybridized to the linearized plasmids $(5 \mu \mathrm{g})$ noted above, which were immobilized on nitrocellulose filters. Radioactivity was visualized by autoradiography. $(A)$ Overnight exposure; $(B)$ 6-day exposure. ginning 30 min prior to NGF stimulation. We then analyzed, by nuclear run-on assay, the levels of $\mathrm{TH}$ transcription in vitro in nuclei isolated from $\mathrm{PCl} 2$ cells during $0-4 \mathrm{hr}$ of NGF treatment. Figure 2A demonstrates that in the presence of protein synthesis inhibitors, the TH gene fails to be induced by NGF. In contrast, the c-fos gene is superinduced by a mechanism independent of protein synthesis (Fig. 2B; Greenberg et al. 1986).

\section{Functional activity of the TH-FSE DNA sequence}

To examine how NGF induces TH gene transcription transiently, we sought to identify the promoter region sequences and transcription factors that regulate the gene. Inspection of the rat TH promoter (Harrington et al. 1987) revealed a potential regulatory element between positions -205 and -193 with homology to a previously characterized regulatory sequence, the FSE, which is found in genes regulated during adipocyte differentiation (Distel et al. 1987). Within the FSE lies a sequence homologous to the 8-bp AP-1-binding site found in both viral and animal genomes (Angel et al. 1987; Lee et al. 1987a,b). The FSE binds the Fos-Jun complex (Rauscher et al. $1988 \mathrm{a}, \mathrm{c}$ ), which is responsive to growth factors and phorbol esters. Of $13 \mathrm{bp}, 11 \mathrm{bp}$ are conserved between the aP2 FSE2 sequence and the THFSE (Fig. 3), with $1 \mathrm{bp}$ difference $(\mathrm{C}$ to $\mathrm{T})$ occurring within the AP-1 site and $1 \mathrm{bp}$ difference (A to C) occurring outside of the AP-1 site (FSE-specific sequence).

We first asked which sequences provide NGF induction and whether the TH-FSE functions in the regulation of $\mathrm{TH}$ gene transcription. We transiently transfected PC12 cells with plasmids that contain various portions of the TH gene $5^{\prime}$-flanking sequence. We employed three constructs that differ in the length of the $5^{\prime}$-flanking-sequence (Fig. 3): p5'THCAT $-773 /+27$, p5'THCAT $-272 /+27$, and p5'THCAT $-151 /+27$ (Lewis et al. 1987). p5'THCAT $-151 /+27$ contains only $151 \mathrm{bp}$ of $5^{\prime}$ untranscribed DNA sequence and lacks the TH-FSE DNA element (positions -205 to -193 ), as well as sequences downstream from this element (i.e., -193 to -152). Plasmids were introduced into $\mathrm{PC1} 2$ cells by electroporation (Potter et al. 1984; Flug et al. 1987), and cells were harvested with or without NGF stimulation for $4 \mathrm{hr}$. We used RNase protection to assay for THCAT (chloramphenicol acetyltransferase) hybrid RNA transcripts. Transcription from the exogenous TH promoter should yield a 192-bp protected fragment composed of a hybrid transcript consisting of 27 bases of $\mathrm{TH}$ plus 165 bases of CAT RNA sequence. Results typical of several trials are shown in Figure 4. A low level of the 192-nucleotide transcript is observed when a plasmid containing either 272- or 773-bp of 5'-untranscribed TH sequence is present in unstimulated PC12 cells (lanes 1 and 5). NGF induces a marked increase in the level of transcripts from the exogenous $-272 /+27$ plasmid (cf. lanes 1 and 2). Transcripts from the $-773 /+27$ plasmid construct are also increased in response to NGF, although to a lesser extent (cf. lanes 5 and 6 to 1 and 2). 


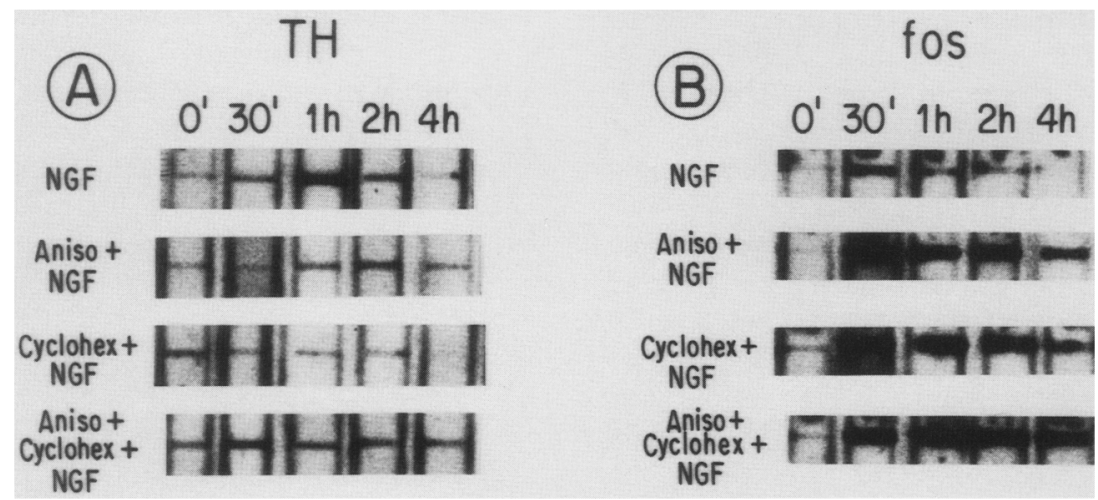

Figure 2. Effect of protein synthesis inhibitors on the kinetics of NGF-induced TH gene transcription. Nuclei were isolated from PCl 2 cells treated with various protein synthesis inhibitors (concentrations noted above), beginning one-half hour prior to NGF stimulation of 0-4 hr. RNA transcripts labeled with ${ }^{32} \mathrm{P}$ were then generated and used for nuclear run-on transcription. Transcription of the TH gene $(A)$ and the c-fos gene, a control, $(B)$ was analyzed by using these assay conditions.

The endogenous $\mathrm{TH}$ gene is also stimulated in these cells (data not shown). These results show that sequences conferring NGF responsiveness are present within the TH $5^{\prime}$ DNA -272 to +27 region. The result with the -773 -bp plasmid construct, in which inducibility of $\mathrm{TH}$ transcripts is not as strong as that with the -272 plasmid construct, further suggests the presence of an element between -773 and -272 , which modu- lates the level of NGF-induced TH gene transcription. Unstimulated PC12 cells transfected with p5'THCAT $-151 /+27$ also yield the 192-nucleotide protected RNA transcript (lane 9) at a level slightly higher than either $-272 /+27$ or $-773 /+27$ plasmids (cf. lane 9 with 1 and 5). No change in the level of TH transcript is observed with this plasmid following NGF induction /cf. lanes 10 and 9), which suggests that sequences downstream of

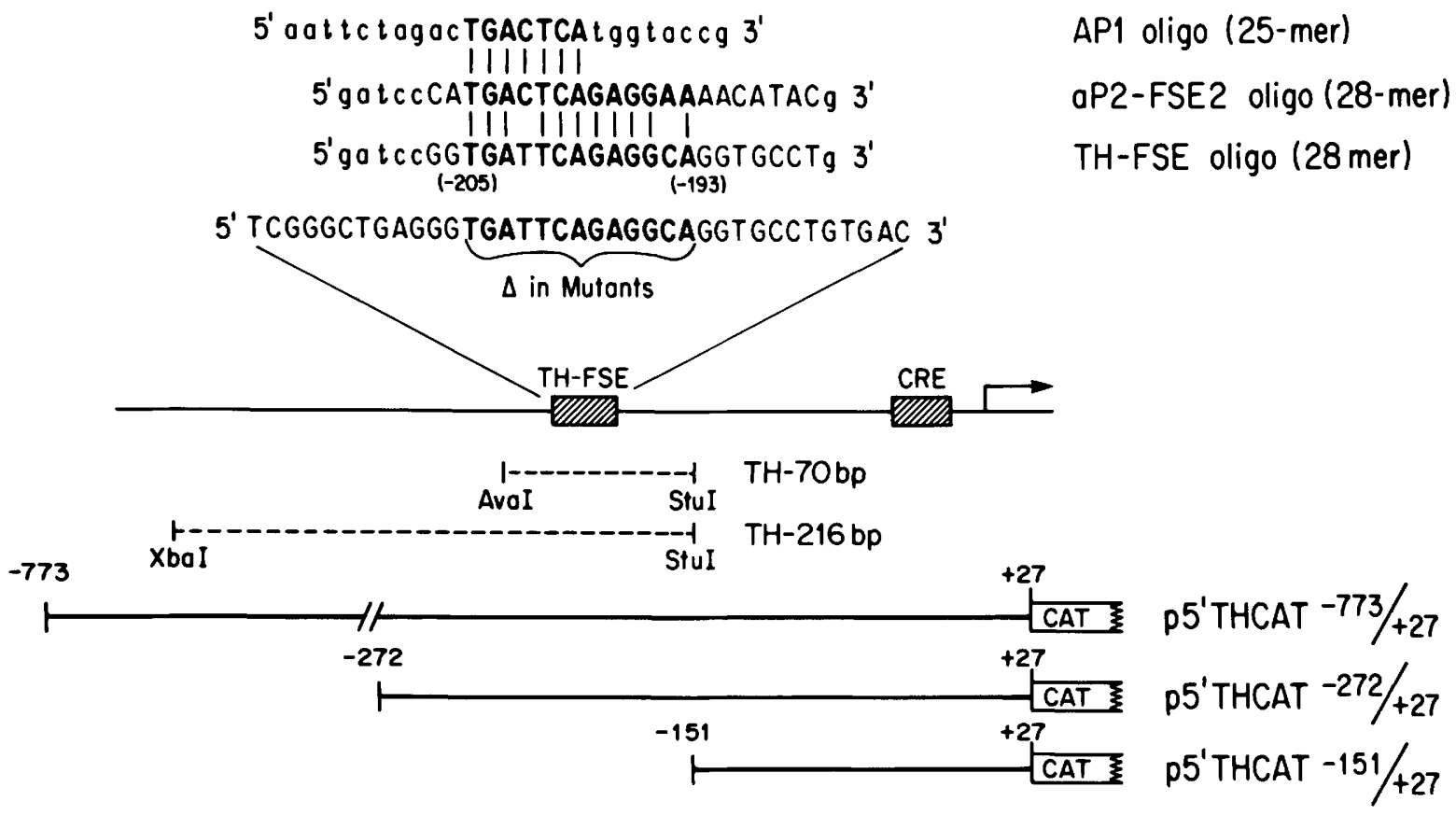

Figure 3. Regulatory DNA regions of the rat TH promoter. The $5^{\prime}$-untranscribed DNA region of the rat $\mathrm{TH}$ promoter (Harrington et al. 1987) is shown and contains a CRE ((Hyman et al. 1988) located at positions -45 to -38 and the TH-FSE DNA element located at positions -205 to -193 . The TH-FSE shares homology with the FSE2 DNA region of the adipocyte-specific gene aP2 (Distel et al. 1987). The TH-FSE is shown in boldface type, together with adjacent flanking sequences (uppercase letters) that are present in the TH promoter. TH-FSE and aP2-FSE2 DNA elements are aligned with one another with the consensus AP-1 sequence site of the human metallothionein gene, hMTII $_{\mathrm{A}}$ (Angel et al. 1987; Lee et al. 1987a,b), shown in boldface type. Oligonucleotides corresponding to each of these sites are also displayed. DNA linker sequences are shown in lowercase letters. TH-CAT plasmid constructs are also shown. Deletion mutants of the plasmid constructs pTHCAT $\triangle$ FSE $-272 /+27$ and pTHCAT $A F S-773 /+27$, described in Methods, lack the 13-bp TH-FSE DNA sequence noted above. Finally, TH DNA restriction fragments used as competitors in gel mobility-shift assays are also indicated. 
-151 are not responsible for NGF regulation. Because the -151 plasmid construct is not NGF inducible and the -272 plasmid construct is, these results further suggest that sequences between -272 and -151 , a region encompassing the TH-FSE, are required for the response to NGF. Sequences in this region may also affect the basal level of transcription from the TH promoter, as the basal level of transcription was elevated in the $-151 /+27$ construct versus the $-272 /+27$ construct.

To test the role of the TH-FSE directly, we used in vitro mutagenesis (Kunkel 1985) to remove the 13-bp TH-FSE DNA element from the $-773 /+27$ and $-272 /+27$ plasmids (Fig. 3) and measured the levels of RNA in transfected uninduced and NGF-induced PC12 cells. Figure 4 shows that in the absence of the TH-FSE DNA element, neither construct expresses RNA in the unstimulated cells (lanes 3 and 7). Strikingly, no transcripts are detected from these deletion DNA plasmid constructs when PC12 cells are stimulated with NGF (lanes 4 and 8). These results suggest that the 13-bp THFSE DNA sequence has a direct role in establishing the basal level of activity of the rat TH gene and is also required for NGF inducibility.

\section{TH-FSE is capable of binding Fos-Jun in vitro}

Given a role for the TH-FSE in establishing the basal activity and NGF inducibility of the TH promoter, we asked whether this sequence is capable of forming sequence-specific DNA-protein complexes in vitro with fos and jun peptide products, as shown previously for the aP2 FSE2 sequence. A 28-bp oligonucleotide corresponding to the TH-FSE DNA element plus several bases of flanking sequence from the authentic rat $\mathrm{TH}$ promoter (see Fig. 3) and the complementary oligonucleotide were synthesized and annealed, and the ${ }^{32} \mathrm{P}$-labeled-TH-FSE was incubated with fos and jun peptides made by in vitro translation in a rabbit reticulocyte system (Kouzarides and Ziff 1988) and gel electrophoresis performed for the gel mobility-shift assay (Strauss and Varshavsky 1984; Carthew et al. 1985). As is evident in Figure 5, the TH-FSE forms a DNA-protein complex when incubated with both fos and jun proteins (lane 3), whereas no binding is detectable when the same oligonucleotide is incubated with either fos or jun proteins alone (lanes 1 and 2). The DNA-protein complex formed between the TH-FSE and the fos and jun proteins comigrates with the complex between Fos and Jun and an oligonucleotide corresponding to the canonical FSE DNA element. The greater intensity in the signal in the FSE lane suggests that this oligonucleotide has a slightly higher affinity for the in vitro-translated fos and jun proteins than the TH-FSE (cf. lanes 3 and 10). An unrelated DNA element NF68, forms no DNA-protein complex with fos and iun proteins (lane 9|. Unlabeled TH-FSE oligonucleotide specifically decreases by competition the formation of the complex formed with fos and jun proteins in lane 4, whereas the heterologous oligonucleotide NF68 does not compete for binding (lane 5), demonstrating the specificity of complex formation. In

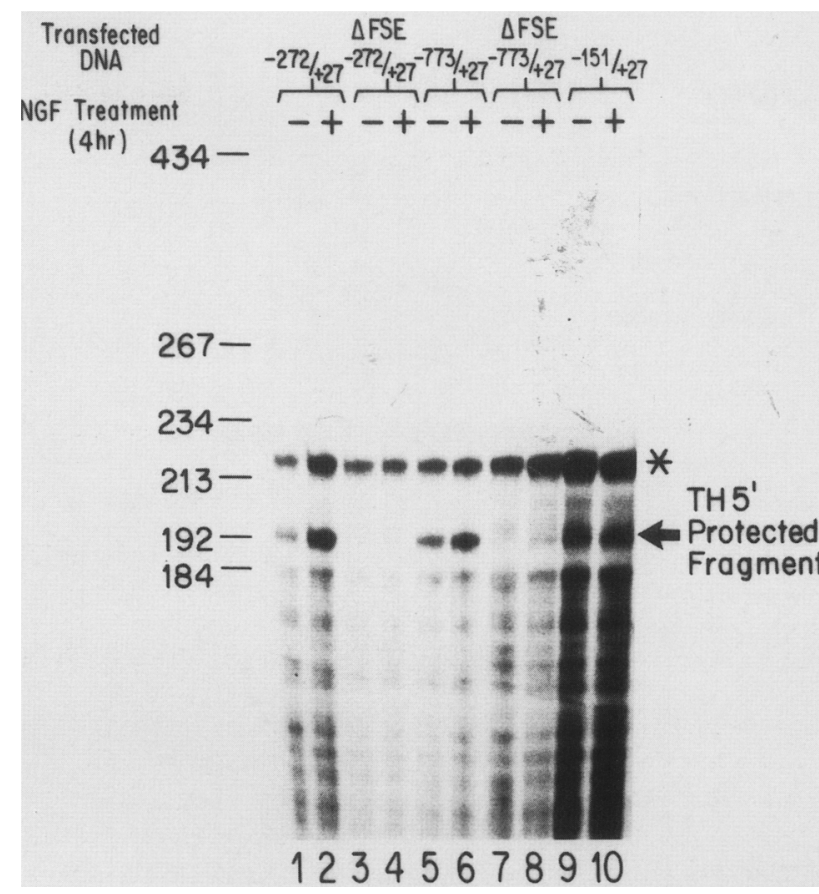

Figure 4. NGF regulation of the rat TH gene in transfected PC12 cells requires the TH-FSE. PC1 2 cells were transfected by electroporation (see Methods) with the following plasmids: wild-type genomic TH-CAT plasmid containing 272 bp of $5^{\prime}$ regulatory sequence p5'THCAT $-272 /+27$ (lanes 1 and 2); a deletion mutant that lacks the TH-FSE sequence from -205 to -193 yet contains all other sequences to $-272 \mathrm{bp}$, pTHCAT $\triangle F S E-272 /+27$ (lanes 3 and 4); wild-type genomic TH-CAT plasmid containing $773 \mathrm{bp}$ of $5^{\prime}$ regulatory sequence, pTH5'CAT $-773 /+27$ (lanes 5 and 6 ); a deletion mutant that lacks the TH-FSE sequence from -205 to -193 , yet possesses all sequences to $-773 \mathrm{bp}$, pTHCAT $\Delta$ FSE $-773 /+27$ (lanes 7 and 81 ; and wild-type genomic TH-CAT plasmid containing only $151 \mathrm{bp}$ of $5^{\prime}$ regulatory sequence in which the TH-FSE is excluded, p5'THCAT $-151 /+27$ (lanes 9 and 10). Cultures were incubated at $37^{\circ} \mathrm{C}$ for $24 \mathrm{hr}$ and were either analyzed unstimulated or following stimulation with NGF (50 ng/ml) for 4 hr. RNA was isolated, and RNase protection was performed as described in Methods. (Lanes 1, 3, 5, 7, and 9) Results with unstimulated RNA; (lanes 2, 4, 6, 8, and 10) results with NGFstimulated cells. The TH transcript 5 '-protected mRNA fragment is 192 nucleotides in length. Background bands $\left({ }^{*}\right)$ were observed consistently in our analysis, which we believe results from aberrant initiation at sites within the constructs used. The presence of these background bands was not regulated by NGF. (Left) Sizes are indicated in bp.

addition, formation of the DNA-protein complex is specifically inhibited by antibodies to either Fos or Jun (lanes 6 and 7) but is unaffected by an antibody generated against an unrelated protein, peripherin (lane 8). These data establish that the TH-FSE binds authentic Fos-Jun heterodimeric complexes.

\section{Sequence-specific binding of NGF-inducible PC12 protein factors}

We then asked whether protein factors present in extracts of PC12 cells could form complex(es) with the 


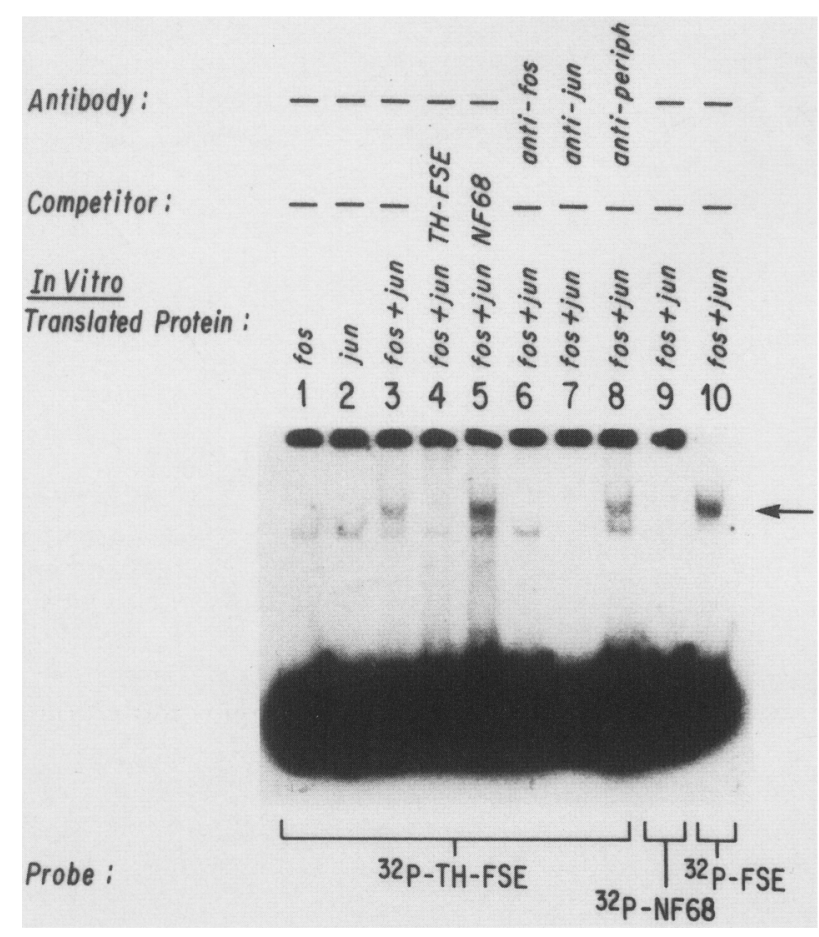

Figure 5. Gel retardation analysis of complexes formed between authentic fos and jun proteins and the TH-FSE. DNAprotein mobility-shift analysis (Strauss and Varshavsky 1984; Carthew et al. 1985; Gilman et al. 1986) was performed using Fos and Jun proteins made by in vitro translation in a rabbit reticulocyte system (Kouzarides and Ziff 1988) and incubated with the ${ }^{32} \mathrm{P}$-labeled TH-FSE. DNA-protein complex formation was assayed with the ${ }^{32} \mathrm{P}$-labeled TH-FSE incubated with Fos alone (lane 1), Jun alone (lane 2), Fos and Jun (lane 3), Fos and Jun plus cold TH-FSE as specific competitor (lane 4), and Fos and Jun plus cold NF68 oligonucleotide (Lewis and Cowan 1988) as a nonspecific competitor (lane 5). Inhibition of complex formation was also analyzed by preincubating Fos and Jun with anti-Fos (lane 6), anti-Jun (lane 7), or anti-peripherin (lane 8 ) antibodies followed by incubation with ${ }^{32} \mathrm{P}$-labeled $\mathrm{TH}$ FSE. Fos and Jun were also incubated with ${ }^{32}$ p-labeled FSE (lane 10) or ${ }^{32}$ P-labeled NF68 (lane 9| to compare resulting binding complexes with that of the ${ }^{32} \mathrm{P}$-labeled TH-FSE (lane 3). The arrow indicates the sequence-specific complex formed and studied in this analysis. A nonspecific band, incapable of sequence specific competition, is also seen.

TH-FSE and whether the time of formation of such complexes corresponded to periods of NGF induction. First, the radiolabeled 28-bp double-stranded TH-FSE was incubated in the presence of nonspecific competitor DNA with nuclear extracts obtained from $\mathrm{PCl} 2$ cells treated for either 1 or $2 \mathrm{hr}$ with NGF. Electrophoresis in a nondenaturing gel reveals one specific complex $(\mathrm{A})$ and one nonspecific complex $(\mathrm{N})$ with nuclear proteins from either extract (Fig. 6A,B, lanes 1). In Figure 6, A and B, complex $\mathrm{A}$ is decreased as a result of competition by unlabeled TH-FSE (lane 2), the FSE sequence (lane 3), and a double-stranded oligonucleotide containing the consensus AP-1 sequence (lane 4), demonstrating that it is sequence specific. Furthermore, complex $A$ is not de- creased as a result of competition by an unrelated double-stranded oligonucleotide that contains the dyad symmetry element of the c-fos gene (Fig. 6A,B, lanes 5). In contrast, complex $\mathrm{N}$ in Figure 6 is not decreased by competition effectively, except by a high molar excess of unlabeled single-stranded oligonucleotide (data not shown).

To further examine the sequence specificity of complex A, unlabeled restriction fragments spanning the TH-FSE region were used as competitor (see Fig. 3). Both the 70-bp AvaI-StuI fragment and a 216-bp XbaI-StuI fragment overlapping the TH-FSE sequence effectively decreased competitively the formation of complex A by the radiolabeled TH-FSE oligonucleotide (Fig. 6A,B, lanes 6 and 7), whereas a nonhomologous DNA fragment of the $\alpha$-tubulin gene does not offer competition (lane 8). The radiolabeled TH-216 bp genomic fragment, itself, also forms a sequence-specific complex with nuclear extracts from stimulated PC12 cells (data not shown). Taken together, these results confirm that the TH-FSE can bind nuclear proteins from PC12 cells in a sequence-specific manner.

\section{Alteration in levels of TH-FSE-nucleoprotein complex following NGF induction}

We noted that the level of DNA-nucleoprotein complexes formed with extract from cells treated for $2 \mathrm{hr}$ with NGF was greater than that for the 1 -hr treated cells (cf. Fig. 6A,B). No alteration in mobility of these complexes was apparent. This suggested that proteins interacting with the TH-FSE may change either in their level or binding capacity during the NGF induction, and that such changes may correlate with changes in the rate of transcription of the $\mathrm{TH}$ gene.

To test this possibility, we assayed complex formation using extracts from cells treated for varying times from 0 hr to 1 day with NGF. Complex A becomes more abundant during this period of NGF stimulation (Fig. 6C). More specifically, a low level of complex is detected with extracts from unstimulated $\mathrm{PC} 12$ cells (Fig. 6C, lane 1), and the abundance of this complex gradually increases following $1 \mathrm{hr}$ of NGF and continues to increase at $2 \mathrm{hr}$ of NGF treatment (Fig. 6C, lanes 3 and 5). A slight difference in mobility of the complex with unstimulated versus 1-hr NGF-stimulated PC12 extracts is observed, although its significance is unknown. The complex reaches a maximum level at $4 \mathrm{hr}$ of NGF treatment and is less abundant at 1 day of NGF stimulation (Fig. 6C, lanes 7 and 91. No variation was seen in the level of serum regulatory factor (SRF) complex with a dyad symmetry element (DSE) oligonucleotide (data not shown), arguing that the changes did not reflect differences in extraction efficiency. These kinetics are in sharp contrast to the time course of TH transcription, which reaches a maximum at $1 \mathrm{hr}$ of NGF stimulation of $\mathrm{PC} 12$ cells and then declines. Thus, the level of TH-FSE DNA-protein complex continues to increase during a period when the transcription rate of the TH gene first increases and then declines. This result suggests that ei- 


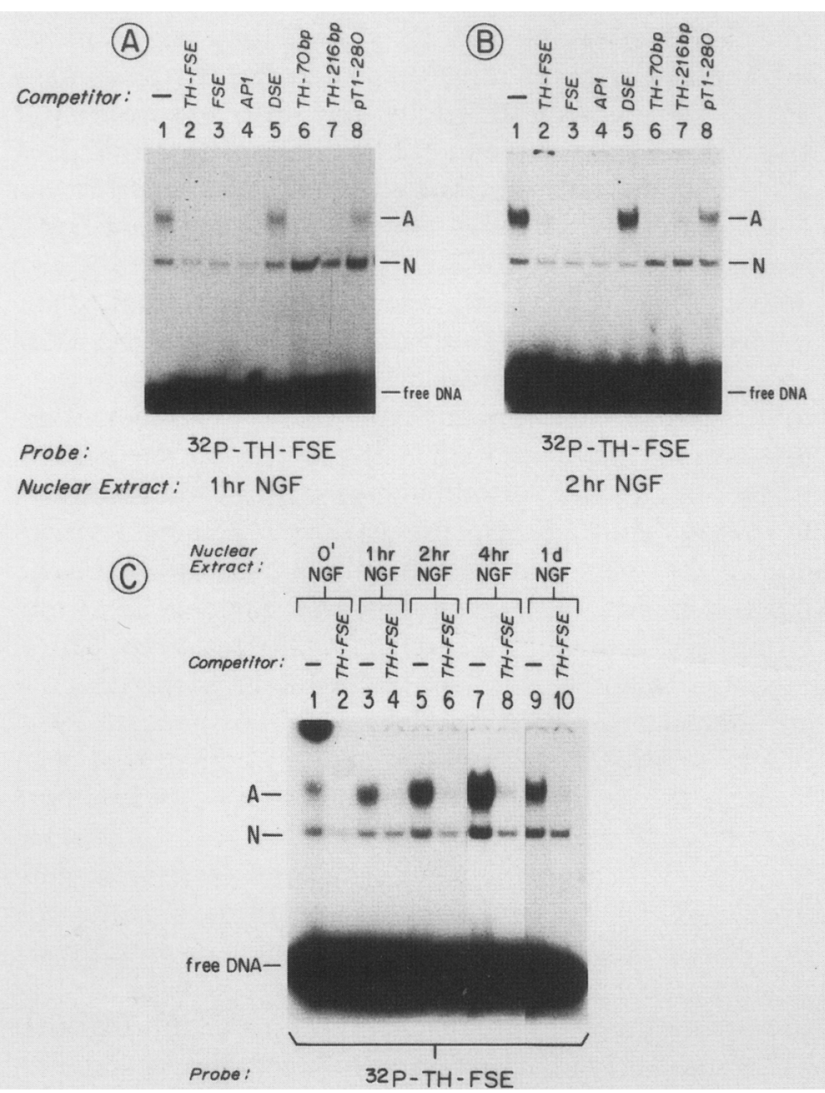

Figure 6. Analysis of DNA-protein complex formation between the TH-FSE and nuclear extracts obtained from NGFtreated PC12 cells. Nuclear extracts were prepared by the method of Dignam et al. (1983) and assayed for complex formation with the ${ }^{32} \mathrm{P}$-labeled-TH-FSE. DNA-protein complexes were formed in $A$ and $B$ with nuclear extracts from 1-hr NGFand 2-hr NGF-treated PC12 cells, respectively. Complexes were formed in the presence of either no competitor (lane 1), unlabeled TH-FSE (lane 2), FSE (lane 3), AP-1 (lane 4), DSE (lane 5), double-stranded unlabeled $\mathrm{TH} 5^{\prime}$ genomic restriction fragments designated TH-70 bp (lane 6), and TH-216 bp (lane 7), or an unlabeled DNA fragment of the rat $\alpha$-tubulin gene $(\mathrm{pT} 1-280$; lane 8). (A description of these oligonucleotides and fragments is given in Methods and in the legend to Fig. 3). (C) DNA-protein complexes formed by the ${ }^{32} \mathrm{P}$-labeled TH-FSE incubated with nuclear extracts obtained from either untreated (lane 1), 1-hr NGF-treated (lane 3), 2-hr NGF-treated (lane 5), 4-hr NGFtreated (lane 7), or 1-day NGF-treated (lane 9) PC12 cells. Competition with unlabeled TH-FSE is also shown (lanes 2, 4, 6, 8, 10). (N) Nonspecific complex, which can be decreased by competition with a high molar excess of homologous or heterologous single-stranded oligomer (data not shown).

ther the level of the complex is unrelated to the rate of $\mathrm{TH}$ gene transcription or that the nature of the complex changes during the intervals of positive and negative control (see below).

Direct involvement of $c$-fos in the nucleoprotein

Previous studies by others have shown that the FSE2 and $\mathrm{hMTII}$ A $-\mathrm{AP}-1$ elements specifically bind a heterodimeric complex of Fos in association with Jun (e.g., Boh- mann et al. 1987; Distel et al. 1987; Chiu et al. 1988; Rauscher et al. 1988a,c). It has been well documented that c-fos protein (Curran and Morgan 1985; Kruijer et al. 1985) is induced in PC12 cells by NGF under conditions employed here for the transient induction of $\mathrm{TH}$ transcription. Because the TH-FSE can bind in vitrotranslated Fos in the presence of Jun and complex A is induced by NGF, we asked whether Fos is present within this complex in vivo. In Figure 7A, we utilized the anti-Fos antibody, anti-FostrpA, generated against a Fos fusion peptide (Vosatka et al. 1989) to see whether the formation of the complex could be inhibited between proteins present in NGF-stimulated PC12 extracts and the radiolabeled TH-FSE. Preincubation of the antibody with $\mathrm{PC} 12$ nuclear extracts obtained after various periods of NGF treatment inhibited the complex from forming (cf. lanes 1, 2, 4, 5, 7, 8, 10, 11, 13, and 14). Whereas antibody concentrations used in Figure $7 \mathrm{~A}$ were sufficient to completely inhibit complex formation at $0-, 1-, 2-\mathrm{hr}$, and 1-day NGF time points, $2 \times$ concentrations were required to completely inhibit the more abundant nucleoprotein complex formed with extract from 4-hr NGF-treated cells (data not shown). Preincubation with a control anti-peripherin antibody did not inhibit the complex (Fig. 7A, lanes 3, 6, 9, 12, and 15).

As an additional control, the anti-Fos antibody was preincubated with or without excess Fos fusion peptide, and the mixture was then incubated with nuclear extracts prepared from either 1- or 4-hr NGF-treated PCl2 cells. Radiolabeled TH-FSE was then added. As seen in Figure 7, B and C, preincubation with the peptide completely reversed the inhibitory effect of the anti-FostrpA antibody (cf. Fig. 7B,C, lanes 2 and 3), indicating that the effect observed is due to specific antigen recognition. These results show that anti-FostrpA antibody is capable of disrupting the protein-DNA complex detected by the mobility-shift assay by using extracts from cells at both early and late times of NGF induction. It should be noted that the FostrpA fusion peptide used to generate the antibody contains a hydrophilic amino acid sequence with antigenically related counterparts found in all members of the fos gene family (Vosatka et al. 1989). Therefore, given the existence of multiple fos gene family members (Franza et al. 1987, 1988; Cohen and Curran 1988; Zerial et al. 1989), we asked whether a Fos-related antigen (Fra), as well as c-fos, could participate in the formation of the DNA-protein complexes in the unstimulated and NGF-stimulated cells.

To determine whether both c-Fos and Fra could contribute to TH-FSE-protein complex formation, we analyzed the PC12 nuclear extracts by Western blot analysis by using anti-FostrpA antibody. We asked whether the presence or absence of various proteins of the fos gene family correlated with changes in binding activity to the TH-FSE and changes in the transcription rate of the TH gene. PC12 cell nuclear extracts obtained after various intervals of NGF treatment were subjected to SDSPAGE, transferred to nitrocellulose, and probed with the anti-FostrpA antibody.

In Figure 8, virtually no Fos is detected in nuclear ex- 


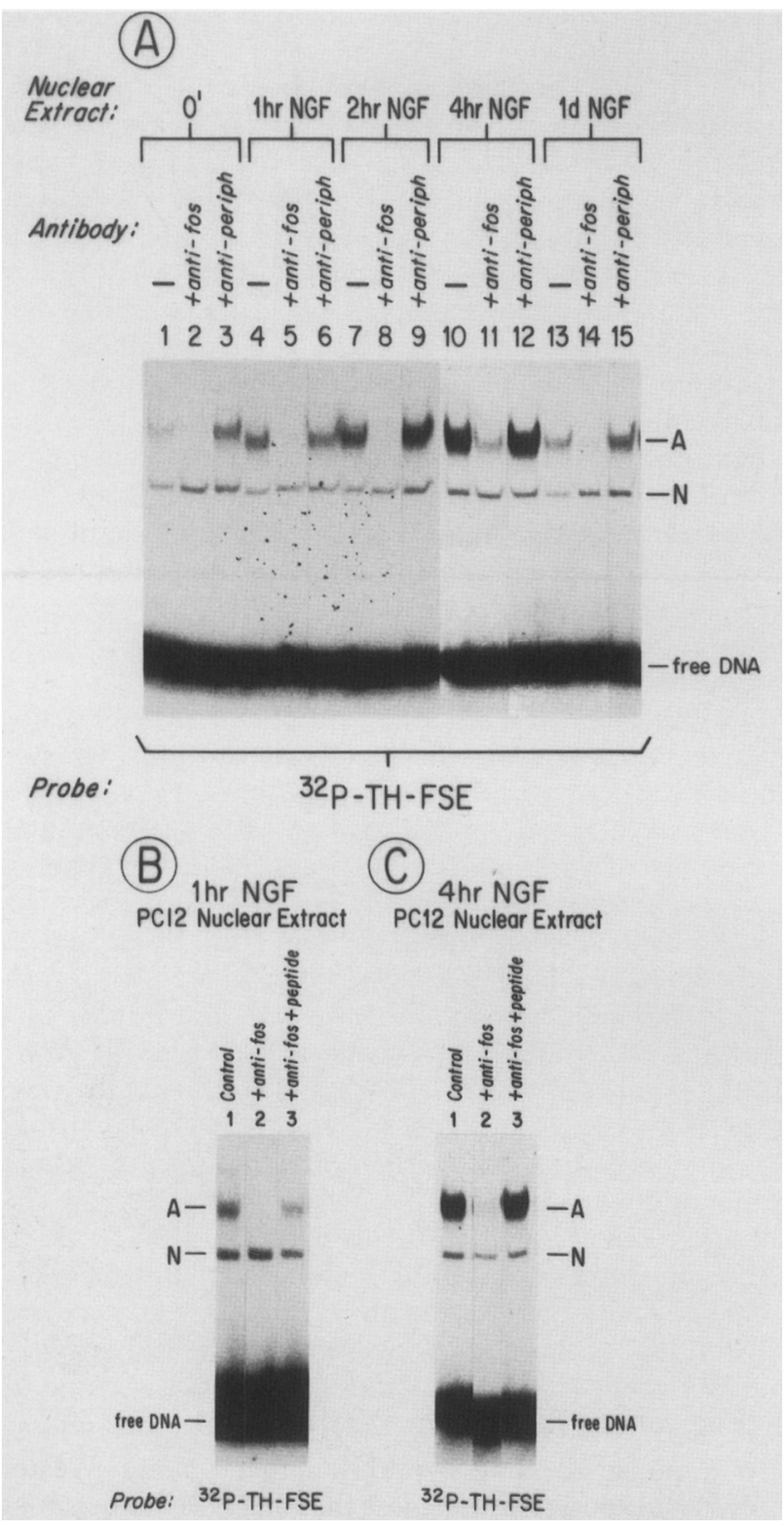

Figure 7. Antibody inhibition of the TH-FSE DNA-protein complex formed following NGF stimulation of PC12 cells differentiation. (A) Nuclear extracts prepared from untreated (lanes 1-3), 1-hr (lanes 4-6), 2-hr (lanes 7-9), 4-hr (lanes 10-12), or 1-day (lanes 13-15) NGF-stimulated PC12 cells were preincubated with either no antibody (lanes 1, 4, 7, 10, 13), anti-Fos antibody (lanes $2,5,8,11,14$ ), or anti-peripherin antibody (lanes $3,6,9,12,15)$ prior to incubation with ${ }^{32}$ P-labeled THFSE. $(B$ and $C)$ Nuclear extracts from PCl2 cells treated for either $1 \mathrm{hr}(B)$ or $4 \mathrm{hr}(C)$ with NGF were assayed for specificity of antibody recognition. Extracts were incubated with ${ }^{32} \mathrm{P}$-labeled TH-FSE directly (lane 1), preincubated with anti-Fos antibody prior to incubation (lane 2), or preincubated with a mixture of anti-Fos antibody and Fos fusion peptide prior to incubation with the ${ }^{32}$ P-labeled TH-FSE (lane 3). The sequence-specific DNA-protein complex $(\mathrm{A})$ and the nonspecific band $(\mathrm{N})$ are indicated. tracts of unstimulated PC12 cells. Only a faint band of the molecular mass range expected for Fra proteins46-48 kD-is seen (Franza et al. 1987). At $1 \mathrm{hr}$ of NGF stimulation, a strong band of Fos is readily visible (lane 2), consistent with previous reports (Curran and Morgan 1985; Kruijer et al. 1985; Franza et al. 1987) that Fos is strongly induced by NGF. A weaker band of Fra is also detected. As the duration of NGF stimulation is extended (i.e., $2 \mathrm{hr}, 4 \mathrm{hr}$, and 1 day), the relative levels of Fos and Fra change (lanes $3-5$ ). fos protein appears to be much less abundant, most likely due to its transient expression and short protein half-life (Muller et al. 1984; Kruijer et al. 1985; Curran and Morgan 1986; Vosatka et al. 1989|. The decrease in Fos levels is most evident during the transition from 2 to $4 \mathrm{hr}$ of NGF treatment. Fos is almost completely absent by 1 day of NGF stimulation. Fos is slightly slower in its migration at $4 \mathrm{hr}$ of NGF treatment versus $1 \mathrm{hr}$, most likely as the result of an increase in phosphorylation (Muller et al. 1984; Franza et al. 1987; Vosatka et al. 1989). The Fra species become the predominant fos gene family products by 4 hr of NGF stimulation of PC12 cells (lane 4), and the Fra protein levels drop slightly by 1 day of NGF treatment (lane 5). This experiment reveals a pattern of expression in which Fos increases and gradually diminishes, whereas Fra increases and maintains its level to become the predominant product during the time interval that $\mathrm{TH}$ transcription is transiently induced. When taken together with the results of mutagenesis of the TH promoter demonstrating dependence on the TH-FSE for NGF inducibility, these results suggest that proteins acting at the TH-FSE have a direct role in regulating the $\mathrm{TH}$ gene and that the nature of this complex changes during the course of NGF-induced differentiation.

\section{Discussion \\ Transcriptional regulation of the TH gene}

We have analyzed the mechanism of transcriptional regulation of the TH gene by NGF. Our results demonstrate that NGF stimulation of $\mathrm{PC} 12$ cells induces transcription of the TH gene with delayed early kinetics. We also show that the mechanism controlling transcription of the TH gene during NGF induction is a multistep process that is reliant on new protein synthesis. During NGF induction, the expression of early response genes, including c-fos, precede the time of induction of $\mathrm{TH}$ transcription. We show that an element of the TH promoter, the TH-FSE, contains a Fos-Jun-binding site that is structurally related to the FSE2 element that functions in adipocyte differentiation. We show that c-Fos in complex with c-Jun can interact with the TH-FSE in vitro and that the element is required in vivo in transient transfection assays for NGF stimulation of TH transcription. These observations lead to a model in which the early response protein c-Fos in complex with c-Jun induces $\mathrm{TH}$ transcription by binding to the $\mathrm{TH}$ FSE. We also show that during the time at which the transcription rate of $\mathrm{TH}$ declines, the relative proportions of fos family members in the induced cell change 


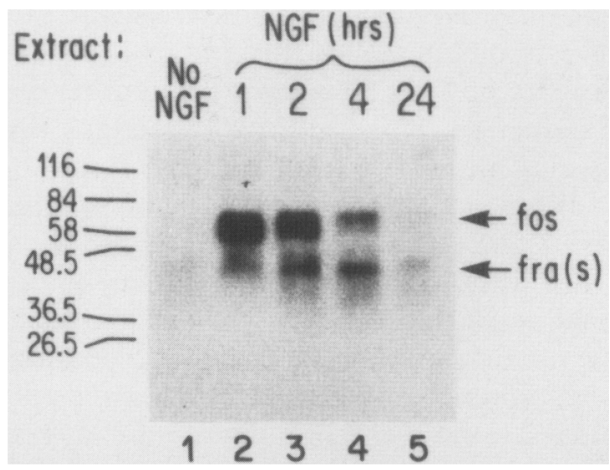

Figure 8. Western blot analysis of the fos family of proteins in NGF-stimulated PC12 cell nuclear extracts. Nuclear protein extracts (15 $\mu \mathrm{g} /$ lane) were electrophoresed on SDS-PAGE, electroblotted, and subjected to Western blot analysis using antiFostrpA antibody, which was detected by ${ }^{125}$ I-labeled protein A, as described in Methods. The nuclear extracts were from untreated, 1-, 2-, 4-, and 24-hr NGF-treated PC12 cells (lanes 1-5, respectively). Migration of Fos and Fra(s) are indicated by arrows. (Left) Protein standards are indicated in kilodaltons.

such that the Fra proteins become relatively more abundant than c-Fos protein itself. The data therefore raise the possibility that at the time $\mathrm{TH}$ transcription is repressed, a Fos-Jun complex at the TH-FSE site is replaced by a complex consisting of Fra proteins bound to Jun or other Jun family members.

Other effectors besides NGF rapidly induce TH gene transcription in pheochromocytoma cell cultures. EGF treatment of PC12 cells also yields a transient induction of $\mathrm{TH}$ transcription very similar to that seen here for NGF (E. Gizang-Ginsberg and E.B. Ziff, unpubl.). EGF treatment of PC12 cells has also been shown to induce c-fos (Greenberg et al. 1985); thus, the mechanism of regulation of TH by EGF may resemble that proposed here for NGF. In the PC cell line, cAMP and glucocorticoids (Lewis et al. 1987) also induce TH transcription, although glucocorticoids direct differentiation toward the chromaffin pathway and NGF induces the neuronal phenotype. In contrast to NGF, for which transcriptional induction is transient, transcription of the $\mathrm{TH}$ gene remains elevated for $24 \mathrm{hr}$ following the induction by glucocorticoids. It is not yet known whether Fos has a role in the induction by these other agents.

\section{Functional importance of the TH-FSE site}

We have provided evidence that a specific DNA sequence element, TH-FSE, plays an important role in the regulation of transcription of the TH gene by NGF. The initial identification of this DNA element was based on homology with the FSE2 sequence (Distel et al. 1987) and other regulatory sequences containing Fos-Junbinding sites (Angel et al. 1987; Lee et al. 1987a,b). The TH-FSE is located between positions -205 to -193 in the $5^{\prime}$-untranscribed region of the TH gene. Our transient transfection studies support the following contentions regarding the functioning of this element.

The basal level expression of TH is dramatically de- creased in the absence of TH-FSE when either 272 or 773 bp of $5^{\prime}$-untranscribed DNA sequence is present. Thus, the TH-FSE DNA sequence functions in the basal level expression of the TH gene. Other regulated DNA sequences, such as the cAMP response element (CRE) of the c-fos gene, have been shown to function as basal control elements and are responsive during EGF (Fisch et al. 1987) and cAMP (Berkowitz et al. 1989) stimulations. Because all TH expression is eliminated when the TH-FSE element is deleted, the TH-FSE may cooperate with other elements to modulate transcription of the TH gene by NGF. Support for this idea is suggested by our results with the p5'THCAT $-151 /+27$ plasmid. p5'THCAT $-151 /+27$, which contains no TH-FSE or adjacent flanking elements from -193 to -151 , is active in unstimulated PC12 cells and is not induced by NGF. This is consistent with NGF control through the TH-FSE and also suggests that additional basal level elements for the TH promoter may lie in the $-151 /+27$ region of the gene. We also find that the TH promoter with 272 bp of $5^{\prime}$-flanking sequence is more strongly induced than with $773 \mathrm{bp}$ of $5^{\prime}$ DNA. This suggests the presence of a negative regulatory element located within the -272 - and -773-bp region. Studies utilizing point mutations of the TH-FSE DNA may distinguish between TH-FSE DNA sequences functioning in basal versus NGF-induced regulation.

\section{TH-FSE-binding proteins and the participation of Fos and Fos-related antigens}

Our results indicate that the TH-FSE is a sequence-specific binding site for in vivo nuclear protein(s) inducible by NGF. Gel mobility-shift studies demonstrate that protein binding to the TH-FSE changes in abundance during NGF-stimulated differentiation, reaching a maximal level at $4 \mathrm{hr}$ following treatment and subsequently decreasing in abundance to a low level by $24 \mathrm{hr}$ of NGF treatment. The gel mobility assay of DNA-protein complexes did not reveal any obvious alterations in complex mobility; therefore, it is difficult to establish whether the complex undergoes any qualitative changes in response to NGF by this approach alone. Western blotting experiments suggest that changes did occur (see below).

Two lines of evidence suggest that the fos family of proteins can contribute to complex formation with the TH-FSE. First, we have shown that the TH-FSE binds fos and jun proteins synthesized by in vitro translation. This is in agreement with the binding potential of the canonical FSE and AP-1 DNA elements (Bohmann et al. 1987; Distel et al. 1987; Chiu et al. 1988; Rauscher et al. 1988a,c). Second, antibody inhibition studies, using an antibody that recognizes amino acid sequences shared by all of the members of the fos protein family, effectively inhibit DNA-protein complex formation by extracts that contain c-Fos as the predominant Fos-related component. Because various investigators have demonstrated that c-Fos binds DNA elements in concert with Jun (Halazonetis et al. 1988; Kouzarides and Ziff 1988; 
Nakabeppu et al. 1988; Rauscher et al. 1988a; SassoneCorsi et al. 1988c; for review, see Curran and Franza 1988), we anticipate that the same Fos-Jun association should hold true in our system. Our results show that fos and jun proteins expressed in vitro can bind in complex with the TH-FSE. We have further attempted to analyze the TH-FSE-nucleoprotein complex for the involvement of Jun during various times of NGF stimulation in PC12 nuclear extracts by using antibody inhibition methodologies (antibody provided by D. Bohmann) similar to those used for examining Fos. These studies have not been successful to date. Hay et al. (1989) were similarly unable to demonstrate any involvement of Jun in the Fos-containing protein complex that controls the c-myc gene. It is possible that the Jun antibody used in our experiments recognizes an antigenic determinant that is not readily accessible when in vivo-synthesized Jun is in complex with Fos at the THFSE site. Alternatively, an inability to detect Jun may reflect a true biological feature of the DNA-binding complex. Franza et al. (1987) have shown that PCl 2 cells contain, in addition to Jun, various Fos-associated proteins in the low-molecular-mass range, $\sim 40 \mathrm{kD}$. These investigators have shown further that although Jun is basic, the p 40 proteins are extremely acidic, suggesting that they are structurally distinct. Therefore, it is possible that Jun may not be associated with Fos in the THFSE-protein complex; perhaps another protein (i.e., one of the $\mathrm{p} 40$ proteins) may serve an analogous function and cooperate with the fos protein gene family in binding to the TH-FSE.

Greenberg and colleagues (Bartel et al. 1989) have shown that in the PC12 cell system, induction of fos, $\mathrm{c}$-jun, and jun-B has distinct programs of activation in response to NGF and EGF versus membrane-depolarizing agents. c-fos, iun-B, and c-iun are all rapidly induced by both NGF and EGF, whereas only c-fos and jun-B are transcriptionally activated by $\mathrm{KCl}$. The temporal appearance of these genes and their corresponding protein products in $\mathrm{PCl} 2$ cells implies that they may provide greater versatility of gene control by generating a diversity of combinational regulatory complexes that allow various subsequent differentiative events to be induced by distinct signal transducing pathways.

How could Fos affect TH gene activity? Our data demonstrate fos expression during the initial phase of NGF induction of $\mathrm{PCl} 2$ cell differentiation (Curran and Moran 1985; Greenberg et al. 1985; Kruijer et al. 1985; Milbrandt 1986). fos expression is transient, and the fos protein is labile (Muller et al. 1984; Kruijer et al. 1985; Curran and Morgan 1985; Franza et al. 1987; Vosatka et al. 1989) and decays within $\sim 1-2 \mathrm{hr}$ following stimulation by growth factors. Our Western blot analysis demonstrates that this is also the case for NGF induction and further demonstrates an increase in the presence of Fra proteins, which parallels the decrease of Fos. We find that the maximal induction of the TH gene transcription occurs $1 \mathrm{hr}$ following NGF treatment. The level of the TH-FSE-nucleoprotein complex increases from 0 to $1 \mathrm{hr}$ and again at $2 \mathrm{hr}$, reaching a maximum at $4 \mathrm{hr}$ and de- clining at 1 day of NGF treatment. We suggest that both Fos and Fra proteins may participate in TH gene control by binding to the TH-FSE sequentially during the course of NGF induction. This exchange of proteins at the THFSE site may allow for alternative functions to be provided at different times during NGF-induced differentiation. For instance, c-Fos may interact with the TH-FSE during the initial times of NGF treatment. Because transcriptional activation occurs at $1 \mathrm{hr}$ of NGF treatment, Fos may serve as a positive regulator according to this model. Fra proteins are then synthesized and potentially substituted at the TH-FSE-binding site at $4 \mathrm{hr}$ NGF treatment to provide a different signal and thereby a different functional role during a period of shutdown of NGF-induced TH gene transcription. Evidence for Fos acting as a trans-acting positive regulator of gene expression has been demonstrated for the $\alpha 1$ (III) collagen gene (Setoyama et al. 1986), the collagenase gene (Schonthal et al. 1988), and the transin gene (Kerr et al. 1988). In addition, other studies have shown that FSE-like or AP-1-containing elements that interact with fos proteins can function as negative regulators of gene expression such as with the adipocyte-specific gene aP2 (Distel et al. 1987), the c-myc gene (Hay et al. 1989), and a region of the human immunodeficiency virus (HIV) long terminal repeat (Franza et al. 1988). The concept that the TH-FSE may be a binding site that allows for alternative functions also has other precedents. In yeast matingtype determination, MCM1 control elements can serve as either positive or negative regulators of a- or $\alpha$-specific genes (Passmore et al. 1989). Alternative proteins that bind adjacent to MCMI determine the effect of the MCMl control element on transcription. Our results show that Fos and/or Fra proteins interact with the THFSE-binding site of the TH gene. Antibodies directed against Fos- or Fra-specific antigenic domains should help to distinguish at which times fos family members are associated with this element. An analysis of transformed PC12 cell lines either stably transfected with an inducible c-fos gene or transiently cotransfected with $\mathrm{c}$-fos- or fra-containing plasmids, along with our $\mathrm{TH}$ plasmid constructs, could further allow us to determine the individual roles of members of the fos gene family in TH gene control during NGF-induced neuronal differentiation.

In this communication we have provided evidence that NGF control of PC12 cell differentiation is regulated by a cascade of gene activity. This series of events includes the activation of an NGF-inducible transcription factor, c-fos, whose product contributes to generating a sequence-specific DNA-nucleoprotein complex within the TH promoter during the growth-factor-induced transcription. This binding complex thereby regulates the TH gene, whose protein product is crucial for neuronal differentiation. The involvement of additional newly synthesized fos protein family members in controlling TH gene activity during NGF induction suggests a pattern of gene regulation of even greater complexity. In the future, it will be important to determine whether this cascade of events is a general phenomenon that also 
occurs in vivo in animal tissues whose differentiation and maintenance are precisely regulated by NGF.

\section{Methods \\ Cell culture and stimulations}

Stock cultures of PC12 cells were maintained in Dulbecco's modified Eagle medium, containing $10 \%$ defined and supplemented calf serum and 5\% horse serum (DMEM; Hyclone Laboratories, Sterile Systems, Inc., Logan, UT) in a humidified $37^{\circ} \mathrm{C}$ incubator with a $10 \% \mathrm{CO}_{2}$ atmosphere. Cells were plated on plastic culture dishes coated with collagen (Collagen Corporation, Palo Alto, CA) at a density of $\sim 3 \times 10^{6}$ cells $/ 10-\mathrm{cm}$ dish prior to all experiments, except where noted. Stimulations with NGF in the presence of fresh media $(50 \mathrm{ng} / \mathrm{ml}$; provided by Dr. Robert Stack, University of Michigan, Flint) were performed 24 hr following plating. When cultures were pretreated with anisomycin $(100 \mu \mathrm{m})$ or cycloheximide $(10 \mu \mathrm{g} / \mathrm{ml})$, the protein synthesis inhibitors were added as concentrated solutions directly to the culture medium. Cells were then stimulated $30 \mathrm{~min}$ later by the addition of NGF.

\section{Nuclear run-on transcription assay}

Experimental procedures for isolation of nuclei and the in vitro nuclear run-on transcription assay have been described previously (Greenberg et al. 1985). The method for binding $5 \mu \mathrm{g}$ of linearized plasmid to nitrocellulose was done as described by Greenberg and Ziff (1984). Sources of cloned plasmid DNAs were as follows: pv-fos (fos; Curran et al. 1982); p-human $\beta$ actin 1 ( $\beta$-actin; Gunning et al. 1983); pv-raf E-H (raf; Rapp et al. 1983); pODC934 (ornithine decarboxylase, ODC ; Berger et al. 1984); pclone 10b, p-clone $15(\mathrm{TH})$, pclone 2, pclone 73 (peripherin), and pclone 74 (Leonard et al. 1987).

\section{Plasmid constructions and mutagenesis}

Plasmids p5'THCAT $-272 /+27$ and p5'THCAT $-773 /+27$ were gifts from Dona Chikaraishi (Lewis et al. 1987). These constructs (Fig. 3) are composed of TH genomic DNA sequence that includes, respectively, 272 or 773 bp of $5^{\prime}$-flanking TH sequence, the transcriptional initiation site, and the first 27 bases of transcribed TH sequence cloned adjacent to a DNA segment coding for the bacterial enzyme chloramphenicol acetyltransferase (CAT) in a pUC-13-derived vector. p5'THCAT - 151/ +27 , which contains only 151 bp of $5^{\prime}$ genomic flanking sequence that excludes the TH-FSE DNA sequence (Fig. 3), was generated by digesting p5' $\mathrm{TH}-773 /+27$ with HindIII and StuI to remove the -773 to -152 DNA fragment and subsequently blunt-ended with Klenow enzyme and religated with T4 DNA ligase. All restriction and modifying enzymes were obtained from New England Biolabs (Beverly, MA) and used according to manufacturer's specifications.

Deletion plasmid constructs pTHAFSE $-272 /+27$, and pTH $\Delta$ FSE $-773 /+27$ that do not contain the TH-FSE DNA sequence (Fig. 3), were generated by in vitro site-specific mutagenesis according to Kunkel (1985). Briefly, a 642-bp EcoRI$X b a I$ DNA fragment containing TH sequence from -363 to +27 plus 252 bp of CAT sequence was obtained and subcloned into EcoRI-XbaI site of Ml3mp18. In vitro mutagenesis was then performed to remove the 13-bp TH-FSE by use of the synthetic oligonucleotide 5'TGCCTCGGGCTGAGGGGGTGCCTGTGAC-3', which is identical to the coding strand. Replicative-form and single-stranded recombinants were prepared (Maniatis et al. 1982), and deletion mutants were confirmed by sequencing (Sanger et al. 1980). To generate the final deletion constructs, a 231-bp ApaI-ApaI DNA fragment $(-217$ to +14$)$ was excised from the above construct and used to replace this same region in p5'THCAT $-773 /+27$ and $5^{\prime}$ THCAT $-272 /+27$. The resulting constructs were designated pTHCAT $\Delta$ FSE $-773 /+27$ and pTHCAT $\Delta$ FSE $-272 /+27$.

To make a plasmid construct for detecting exogenous $\mathrm{TH}$ mRNA transcripts for our transfection studies by RNase protection analysis, a DraI-DraI DNA fragment of p5'THCAT $-272 /+27$ was excised and blunt-ended, and $X b a I$ linkers were added and subcloned into the $X b a I$ site of pGEM3. RNA probe generated from this construct, pTH56.CAT167, protects a 192nucleotide THCAT hybrid mRNA in our studies.

Finally, two genomic 5'TH DNA fragments (Fig. 3) that span the TH-FSE DNA sequence region were isolated to be used for gel mobility-shift competitions. TH-70 bp was excised from p5'TH $-272 /+27$ with ApaI/StuI digestion, whereas TH-216

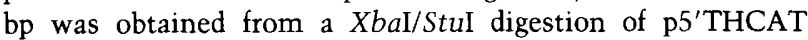
$-773 /+27$. pTl, an embryonic $\alpha$-tubulin cDNA-containing plasmid (Cleveland et al. 1980), was digested with PstI to obtain a 280-bp DNA fragment for competition studies.

\section{Synthetic DNA oligonucleotides}

Oligonucleotides used in gel retardation studies were synthesized on an Applied Biosystems automatic DNA synthesizer and purified by denaturing polyacrylamide gel electrophoresis. The 28-bp oligonucleotide, containing the TH-FSE and flanking region with BamHI linkers, and the oligonucleotide for the AP-1 consensus sequence, which was from the human metallothionein $\mathrm{II}_{\mathrm{A}}$ gene (Lee et al. 1987a), were synthesized and are illustrated in Figure 3. The complementary strand was also made and used for annealing. Double-stranded oligonucleotides have been described previously for the FSE (Kouzarides and Ziff 1988; Fig. 3) and the DSE of c-fos; (Metz et al. 1988). An oligonucleotide corresponding to the 5 -flanking DNA region $(-136$ to -105 ) of the NF68 gene (neurofilament protein; Lewis and Cowan 1986) was kindly provided by Nick Cowan.

\section{In vitro transcription and translation}

To express fos and jun proteins, a fos rat cDNA cloned into the EcoRI site of pGEM3 (Curran et al. 1987; Kouzarides and Ziff 1988) and a c-jun clone in pBSSK (Turner and Tjian 1989) were used. In vitro transcription of the constructs $(1 \mu \mathrm{g})$ and subsequent in vitro translation of one-quarter of the product was made in a rabbit reticulocyte lysate in the presence of $\left[{ }^{35} \mathrm{~S}\right] \mathrm{me}$ thionine, as described by Kouzarides and Ziff (1988).

\section{Nuclear extract preparation and gel retardation assays}

PC12 nuclear extracts were prepared from unstimulated and NGF-stimulated cell cultures, essentially as described by Dignam et al. (1983). The nuclear extracts were dialyzed overnight against $\mathrm{BC} 100$ buffer $10.02 \mathrm{M}$ HEPES at $\mathrm{pH} 7.9,0.1 \mathrm{~mm}$ KCL, $0.2 \mathrm{~mm}$ EDTA, $20 \%$ glycerol, $0.5 \mathrm{~mm}$ dithiothreitol, 0.5 $\mathrm{mM}$ phenylmethylsulfonylfluoride) at $4^{\circ} \mathrm{C}$, aliquoted, and frozen at $-70^{\circ} \mathrm{C}$. Protein concentrations were determined using the Bio-Rad protein assay kit (Richmond, CA).

For DNA-protein binding reactions, $0.2 \mathrm{ng}$ of kinased ${ }^{32} \mathrm{P}-\mathrm{la}-$ beled oligonucleotide $(1 \mu \mathrm{l})$ was mixed with $3 \mu \mathrm{g}$ poly $[\mathrm{d}(\mathrm{I}-\mathrm{C})] / 3$ $\mu 1$; Pharmacia LKB Technology Inc, Piscataway, NJ), $100 \mathrm{ng}$ of nonspecific single-stranded oligonucleotide $(2 \mu 1), \quad B C 100$ without glycerol $(15 \mu 1)$, and $15 \mu \mathrm{g}$ of PC12 nuclear extract (10 $\mu l)$ for $30 \mathrm{~min}$ at room temperature, in conditions similar to those described by others (Strauss and Varshavsky 1984; 
Carthew et al. 1985|. Competition experiments included $100 \mathrm{ng}$ of unlabeled, double-stranded oligonucleotide (TH-FSE, FSE, AP-1, DSE, or NF68) or $0.5-1.0 \mu \mathrm{g}$ of unlabeled DNA fragment (TH-70, TH-216, or pTI-280) in the reaction mixture. Inhibition of DNA-protein complex binding with antibodies was performed by adding either anti-FostrpA (Vosatka et al. 1989) or antiperipherin (control; J. Gorham, D. Kegler, and E. Ziff; unpubl.) to the nuclear extract in binding buffer for $1 \mathrm{hr}$ at $4^{\circ} \mathrm{C}$ prior to the addition of the labeled probe. The preincubation of the Fos antibody with its corresponding fusion peptide or control peptide was conducted for $60 \mathrm{~min}$ at $4^{\circ} \mathrm{C}(0.5 \mu \mathrm{g}$ of antibody, $5 \mu \mathrm{g}$ of peptide) prior to complex formation. Binding assays with in vitro-translated proteins were carried out as described by Kouzarides and Ziff (1988). DNA-protein complexes were resolved on $4.0 \%$ polyacrylamide gels $(30: 0.8$ acrylamide/bis-acrylamide) using conditions described previously (Gilman et al. 1986).

\section{Transient cell transfections and RNA protection analysis}

Transfection of PC12 cells was performed using electroporation (Potter et al. 1984; Flug et al. 1987). Briefly, cells were cultured in DMEM (with fresh media given to cells $24 \mathrm{hr}$ prior to the day of transfection), and $6.0 \times 10^{7}$ cells were harvested as cell pellets for each DNA sample used for transfection. Supercoiled pTH-CAT constructs $(20 \mu \mathrm{g})$ in $30 \mu \mathrm{TE}(1 \mathrm{~mm}$ Tris at $\mathrm{pH} 8.0$, $0.2 \mathrm{mM}$ EDTA) were added to $0.4 \mathrm{ml}$ of Dulbecco's phosphatebuffered saline containing $10 \mathrm{~g} / \mathrm{liter}$ of glucose (PBS-g) and used to resuspend the cell pellets. The cell and DNA mixture was then added to prechilled gene pulser cuvettes $\langle 0.4 \mathrm{~cm}$, electrode gap; Bio-Rad) on an ice slurry. The cells received a 1.5- to 1.6$\mathrm{kV}$ pulse at $0.9 \mathrm{~mA}$ maximum amperage with an Isco model 494 power supply. Ten minutes later, the cells were transferred to $1.5 \mathrm{ml} \mathrm{PBS}-\mathrm{g}$ containing $10 \%$ defined and supplemented calf serum (Hyclone Laboratories), allowed to incubate on ice for 10 $\mathrm{min}$, and distributed to four collagen-coated 10-cm dishes containing DMEM. Routinely, two plates were stimulated with 50 $\mathrm{ng} / \mathrm{ml} \mathrm{NGF}$ for $4 \mathrm{hr}$ following a $24-\mathrm{hr}$ incubation period at $37^{\circ} \mathrm{C}$, whereas two plates remained unstimulated. RNA was harvested using the hot-acid phenol procedure (Queen and Baltimore 1983) from transfected cells of both stimulated states simultaneously and treated with DNase for $30 \mathrm{~min}$ at $37^{\circ} \mathrm{C}$.

Hybrid TH-CAT mRNA transcripts were detected by the RNase protection method described previously (Triesman 1985; Greenberg et al. 1987). RNA $(20 \mu \mathrm{g})$ was hybridized with ${ }^{32}$ P-labeled antisense RNA generated from pTH56.CAT167 in each reaction. RNase-resistant fragments were separated on $6 \%$ polyacrylamide $/ 8 \mathrm{M}$ urea gels and visualized by autoradiography. pBR322 DNA digested with HaeIII was used as approximate size markers.

\section{Western blot analysis}

Nuclear extracts for $\mathrm{PC} 12$ cells $(15 \mu \mathrm{g})$ were heated to $100^{\circ} \mathrm{C}$ for $3 \mathrm{~min}$ in Laemmli sample buffer and loaded onto 10\% SDS/ polyacrylamide gels (Laemmli 1970). After electrophoresis, proteins were transferred to nitrocellulose in $0.025 \mathrm{mM}$ Tris $(\mathrm{pH}$ 8.3), $0.192 \mathrm{M}$ glycine, $20 \%$ methanol, and $0.05 \%$ SDS (Twobin et al. 1979) for $1 \mathrm{hr}$ at $200 \mathrm{~mA}$ at $4^{\circ} \mathrm{C}$. Following electroblotting, the nitrocellulose filter was incubated in $3 \%$ gelatin in 1 TS buffer $(0.05 \mathrm{M}$ Tris at $\mathrm{pH} 8.0,0.15 \mathrm{mM} \mathrm{NaCl} ; 0.02 \%$ sodium azide) for $1 \mathrm{hr}$ at room temperature with shaking, followed by 4 $\mathrm{hr}$ in $5 \%$ nonfat dry milk in $1 \mathrm{TS}$ at room temperature incubation. The filter was then incubated in $3 \%$ nonfat dry milk in 1 TST [TS plus Tween- $20(0.05 \%)]$ in the presence of a $1: 100$ dilution of anti-FostrpA antibody $(100 \mathrm{ng} / \mu \mathrm{l})$ overnight at $4^{\circ} \mathrm{C}$ with shaking. Sequential washes in 1 TST with Tween (five times for $10 \mathrm{~min}$ ) was then performed. Antigen-antibody complexes were detected by incubating ${ }^{125}$ I-labeled protein A (New England Nuclear, Wilmington, Delaware; $9.32 \mu \mathrm{Ci} / \mu \mathrm{g}$ ) in $3 \%$ nonfat dry milk in $1 \mathrm{TST}$ for $1 \mathrm{hr}$ at room temperature with shaking, washing in 1 TST five times for $10 \mathrm{~min}$ each, and subsequently autoradiographing by exposure at $-70^{\circ} \mathrm{C}$.

\section{Acknowledgments}

We thank Anna Velcich, Mary Ann Thompson, and Zahava Siegfried for critical reading of this manuscript, as well as other members of the Ziff laboratory for their helpful discussion. We also thank Dona Chikaraishi for providing us with the parental TH-CAT plasmid constructs, Tony Kouzarides for in vitro-expressed fos and jun protein, Rick Metz for affinity-purifying the anti-Fos antibody, Jim Gorham for anti-peripherin antibody, and Dirk Bohmann for providing us with anti-Jun antibody. The help of Bernie Goldschmidt for the synthesis of oligonucleotides, Heinz Annus for excellent photographic reproduction, and Tony DeMalio for expert preparation of this manuscript is also appreciated. This work was supported by grants from the American Parkinson Disease Association and from the $\mathrm{Na}$ tional Institute of Health (CA-44042) (to Edward B. Ziff), and by grant $\mathrm{MH}-35976$ from the National Institute of Health to A. Friedhoff of the New York University Mental Health Clinical Research Center. E.G.-G. acknowledges a postdoctoral fellowship grant (PF-3052) from the American Cancer Society.

\section{References}

Acheson, A.L., K. Naujoks, and H. Thoenen. 1984. Nerve growth factor-mediated enzyme induction in primary cultures of bovine adrenal chromaffin cells: Specificity and level of regulation. J. Neurosci. 4: 1771-1780.

Almendral, J.M., D. Sommer, H. MacDonald-Bravo, J. Burckhardt, J. Perera, and R. Bravo. 1988. Complexity of the early genetic response to growth factors in mouse fibroblasts. Mol. Cell. Biol. 8: 2140-2148.

Aloe, L. and R. Levi-Montalcini. 1979. Nerve growth factor-induced chromaffin cells in vivo into sympathetic neurons: Effect of anti-serum to nerve growth factor. Proc. Natl. Acad. Sci. 76: 1246-1250.

Anderson, D.J. and R.A. Axel. 1986. A bipotential neuroendocrine precursor whose choice of cell rate is determined by NGF and glucocorticoids. Cell 47: 1079-1090.

Angel, P., M. Imagawa, R. Chiu, B. Stein, R.J. Imbra, H.J. Rahmsdorf, C. Jonat, P. Herrlich, and M. Karin. 1987. Phorbol ester-inducible genes contain a common cis element recognized by a TPA-modulated trans-acting factor. Cell 49: 729-739.

Bartel, D.P., M. Sheng, L.F. Law, and M.E. Greenberg. 1989. Growth factors and membrane depolarization activate distinct programs of early response gene expression: Disassociation of fos and jun interaction. Genes Dev. 3: 304-313.

Berger, F.G., P. Szymanski, E. Read, and G. Watson. 1984. Androgen-regulated orinthine decarboxylase mRNAs of mouse kidney. I. Biol. Chem. 259: 7941-7946.

Berkowitz, L.A., K.T. Riabowol, and M.Z. Gilman. 1989. Multiple sequence elements of a single functional class are required for cyclic AMP responsiveness of the mouse c-fos promoter. Mol. Cell Biol. 9: 4272-4281.

Bohmann, D., T.J. Bos, A. Admon, T. Nishimura, P.K. Vogt, and R. Tjian. 1987. Human proto-oncogene c-jun encodes a DNA binding protein with structural and functional properties of transcription factor AP-1. Science 238: 1386-1392. 
Campbell, D.G., G. Hardie, P.R. Vuilliet. 1986. Identification of four phosphorylation sites in the M-terminal region of tyrosine hydroxylase. Biol. Chem. 261: 10489-10492.

Carthew, R.W., L.A. Chodosh, and P.A. Sharp. 1985. An RNA polymerase II transcription factor binds to an upstream element in the adenovirus major late promoter. Cell 43: 439448.

Chiu, R., W.J. Boyle, J. Meek, T. Smeal, T. Hunter, and M. Karin. 1988. The c-Fos protein interacts with c-Jun/AP-1 to stimulate transcription of AP-1 responsive genes. Cell 54: $541-552$.

Cho, K-O. W.C. Skarnes, B. Minsk, S. Palmieri, L. JacksonGrusby, and J.A. Wagner. 1989. Nerve growth factor regulates gene expression by several distinct mechanisms. Mol. Cell. Biol. 9: 135-143.

Christy, B.A., L.F. Lau, and D. Nathans. 1988. A gene activated in mouse $3 \mathrm{~T} 3$ cells by serum growth factors encodes a protein with 'zinc finger' sequences. Proc. Natl. Acad. Sci. 85: 7857-7861.

Cleveland, D.W., M.A. Lopata, R.J. MacDonald, N.J. Cowan, W.J. Rutter, and M.W. Kirschner. 1980. Number and evolutionary conservation of $\alpha$ and $\beta$-tubulin and cytoplasmic $\beta$ and $\gamma$ actin genes using specific cloned cDNA probes. Cell 20: $95-105$.

Cochran, B.H, A.C. Reffel, and C.D. Stiles. 1983. Molecular cloning of gene sequences regulated by platlet-derived growth factor. Cell 33: 939-947.

Cohen, D.R. and T. Curran. 1988. Fra-1: A serum-inducible, immediate early gene that encodes a fos-related antigen. Mol. Cell. Biol. 8: 2063-2069.

Curran, T. and B.R. Franza Jr. 1988. Fos and Jun: The AP-1 connection. Cell 55: 395-397.

Curran, T. and J.I. Morgan. 1985. Superinduction of c-fos by nerve growth factor in the presence of peripherally active benzodiazepines. Science 229: 1265-1268.

- 1986. Barium modulates c-fos expression and posttranslational modification. Proc. Natl. Acad. Sci. 83: 85218524.

Curran, T. and N.M. Teich. 1982. Candidate product of the FBJ murine osteosarcoma virus oncogene: Characterization of a 55,000-dalton phosphoprotein. I. Virol. 42: 114-122.

Curran, T. and I.M. Verma. 1984. FBR murine osteosarcoma virus. I. Molecular analysis and characterization of a 75,000 Da gag-fos fusion product. Virology 135: 218-228.

Curran, T., M.S. Tordon, K.L. Rubino, and L.C. Sambucetti. 1987. Isolation and characterization of the c-fos (rat) cDNA and analysis of post-translational modification in vitro. Oncogene 2: 80-84.

Curran, T., G. Peters, C. Van Beveren, N. Teich, and I.M. Verma. 1982. FBJ murine osteosarcoma virus: Identification and molecular cloning of biologically active proviral DNA. I. Virol. 44: 674-682.

Dignam, J.D., R.M. Lebowitz, and R.G. Roeder. 1983. Accurate transcription initiation by RNA polymerase II in a soluble extract from isolated mammalian nuclei. Nucleic Acids Res. 14: $1475-1489$.

Distel, R.J., H-S. Ro, B.S. Rosen, D.L. Groves, and B. M. Speigelman. 1987. Nucleoprotein complexes that regulate gene expression in adipocyte differentiation: Direct participation of c-fos. Cell 49: 835-844.

Doupe, A.J., P.H. Patterson, and S.C. Landis. 1985. Environmental influences in the development of neural crest derivates: glucocorticoids, growth factors and chromaffin cell plasticity. I. Neurosci. 5: 2119-2142.

Edgar, D.H. and H. Thoenen. 1978. Selective enzyme induction in a nerve growth factor-responsive pheochromocytoma cell line PC12. Brain Res. 154: 186-190.

Fisch, T.M., R. Prywes, and R.G. Roeder. 1987. c-fos sequence necessary for basal expression and induction by epidermal growth factor, 12-O-tetradecanoyl phorbol-13-acetate and the calcium ionophore. Mol. Cell Biol. 7: 3490-3502.

Flug, F., R.P. Copp, J. Casanova, Z.D. Horowitz, L. Janocko, M. Plotnick, and H. Samuels. 1987. Cis-acting elements of the rat growth hormone gene which mediates basal and regulated expression by thyroid hormone. I. Biol. Chem. 262: 6373-6382.

Franza Jr., B.R., F.J. Rauscher III, and T. Curran. 1988. The fos complex and fos-related antigens recognize elements that contain AP-1 binding sites. Science 239: 1150-1153.

Franza Jr., B.R., L.C. Sambucetti, D.R. Cohen, and T. Curran. 1987. Analysis of fos protein complexes and fos-related antigens by high-resolution two-dimensional gel electrophoresis. Oncogene 1: 213-221.

Gilman, M.Z., R.N. Wilson, and R.A. Weinberg. 1986. Multiple protein-binding sites in the $5^{\prime}$-flanking region regulate c-fos expression. Mol. Cell. Biol. 6: 4305-4316.

Goodman, R. and H.R. Herschmann. 1978. Nerve growth factor-mediated induction of tyrosine hydroxylase in a clonal pheochromocytoma cell line. Proc. Natl. Acad. Sci. 75: 4587-4590.

Goodman, R., E. Slater, and H.R. Herschmann. 1980. Epidermal growth factor induces tyrosine hydroxylase in a clonal pheochromocytoma cell line PC-G2. J. Cell Biol. 84: 495500 .

Greenberg, M.E. and E.B. Ziff. 1984. Stimulation of 3T3 cells induces transcription of the c-fos proto-oncogene. Nature 311: 433-438.

Greenberg, M.E., L.A. Greene, and E.B. Ziff. 1985. Nerve growth factor and epidermal growth factor induce transient changes in proto-oncogene transcription in $\mathrm{PC} 12$ cells. $J$. Biol. Chem. 260: 14101-14110.

Greenberg, M.E., A.L. Hermanowski, and E.B. Ziff. 1986. Effect of protein synthesis inhibitors on growth factor activation of c-fos, c-myc, and actin gene transcription. Mol. Cell. Biol. 6: $1050-1057$.

Greenberg, M.E., Z. Siegfried, and E.B. Ziff. 1987. Mutation of the c-fos gene dyad symmetry element inhibits serum inducibility of transcription in vivo and the nuclear regulatory factor binding in vitro. Mel. Cell. Biol. 7: 1217-1225.

Greene, L.A. and A.S. Tischler. 1976. Establishment of a nonadrenergic clonal line of rat adrenal pheochromocytoma cells which respond to nerve growth factor. Proc. Natl. Acad. Sci. 23: $2424-2428$.

Greene, L.A. and A.S. Tischler. 1982. PC12 pheochromocytoma cultures in neurobiological research. Adv. Cell. Neurobiol. 3: $373-414$.

Gunning, P., P. Ponte, H. Okhayama, J. Engel, H. Blau, and L. Kedes. 1983. Isolation and characterization of full-length cDNA clones for human $\alpha, \beta$, and $\gamma$-actin mRNAs: Skeletal but not cytoplasmic actins have an amino-terminal cysteine that is subsequently removed. Mol. Cell. Biol. 3: 787-795.

Halazonetis, T.D., K. Georgopoulos, M.E. Greenberg, and P. Leder. 1988. C-jun dimerizes with itself and with c-fos, forming complexes of different DNA binding affinities. Cell 55: 917-924.

Hanbauer, I., A. Guidotti, and E. Costa. 1975. Dexamethasone induces tyrosine hydroxylase in sympathetic ganglia but not in adrenal medulla. Brain Res. 85: 527-531.

Harrington, C.A., E.J. Lewis, D. Krzemien, and D.M. Chikaraishi. 1987. Identification and cell type specificity of the ty- 
rosine hydroxylase gene promoter. Nucleic Acids Res. 15: $2363-2384$.

Hatanaka, H. 1981. Nerve growth factor-mediated stimulation of tyrosine hydroxylase activity in a clonal rat pheochromocytoma cell line. Brain Res. 222: 225-233.

Hay, N., M. Takimoto, and J.M. Bishop. 1989. A Fos protein is present in a complex that binds a negative regulator of $\mathrm{Myc}$. Genes Dev. 3: 293-303.

Hazel, T.G., D. Nathans, and L.F. Lau. 1988. A gene inducible by serum growth factors encodes a member of the steroid and thyroid hormone receptor superfamily. Proc. Natl. Acad. Sci. 85: 8444-8448.

Hirai, S.I., R.P. Ryseck, F. Mechta, R. Bravo, and M. Yaniv. 1989. Characterization of junD: A new member of the jun proto-oncogene family. EMBO I. 8: 1433-1439.

Hyman, S.E., M. Comb, Y-S. Lin, J. Pearlberg, M.R. Green, and H.M. Goodman. 1988. A common trans-acting factor is involved in transcriptional regulation of neurotransmittter genes by cyclic AMP. Mol. Cell. Biol. 8: 4225-4233.

Kerr, L.D., J.T. Holt, and L.M. Matrisian. 1988. Growth factors regulate transin gene expression by c-fos dependent and c-fos independent pathways. Science 242: 1424-1427.

Konig, H., H. Ponta, U. Rahmsdorf, M. Buscher, A. Schonthal, H.J. Rahmsdorf, and P. Herrlick. 1989. Autoregulation of fos: The dyad symmetry element as the major target of repression. EMBO J. 8: 2559-2566.

Kouzarides, T. and E. Ziff. 1988. The role of the leucine zipper in the fos-jun interaction. Nature 336: 646-651.

Kruijer, W., D. Schubert, and I.M. Verma. 1985. Induction of the proto-oncogene fos by nerve growth factor. Proc. Natl. Acad. Sci. 82: $7330-7334$.

Kumakara, K., A. Guidotti, and E. Costa. 1979. Primary culture of chromaffin cells: Molecular mechanism for the induction of tyrosine hydroxylase mediated by 8 -Br-cyclic AMP. Mol. Pharmacol. 16: 865-876.

Kunkel, T.A. 1985. Rapid and efficient site-specific mutagenesis without phenotype selection. Proc. Nat1. Acad. Sci. 82: $488-492$.

Laemmli, U.D. 1970. Cleavage of structural proteins during the assembly of the head of bacteriophage T4. Nature 227: 680685.

Landis, S.C. and P.H. Patterson. 1981. Neural crest cell lineages. Trends Neurosci. 4: 172-175.

Lau, L.F. and D. Nathans. 1985. Identification of a set of genes expressed during the G0/G1 transition of cultured mouse cells. $E M B O$ J. 4: 3145-3151.

. 1987. Expression of a set of growth-related immediate early genes in BALB/c 3T3 cells: Coordinate regulation with c-fos or C-myc. Proc. Natl. Acad. Sci. 84: 1182-1186.

Lee, W., P. Mitchell, and R. Tjian. 1987a. Purified transcription factor AP-1 interacts with TPA-inducible enhancer elements. Cell 49: 741-752.

Lee, W., A. Haslinger, M. Karin, and R. Tjian. 1987b. Two factors that bind and activate the human metallothionein $\mathrm{II}_{\mathrm{A}}$ gene in vitro also interact with the SV40 promoter and enhancer regions. Nature 325: 368-372.

Leonard, D.G.B., E.B. Ziff, and L.A. Greene. 1987. The detection and characterization of messenger RNAs regulated by nerve growth factor in PC12 cells. Mol. Cell. Biol. 7: 3156-3167.

Leonard, D.G., J.D. Gorham, P. Cole, L.A. Greene, and E.B. Ziff. 1988. A nerve growth factor-regulated messenger RNA encodes a new intermediate filament protein. I. Cell Biol. 106: $181-193$.

Levi-Montalcini, R. 1966. The nerve growth factor: Its mode of action on sensory and sympathetic nerve cells. Harvey Lect. 60: $217-259$.
Levi-Montalcini, R. and R.V. Angeletti. 1968. Nerve growth factor. Physiol. Rev. 49: 534-569.

Lewis, E.J. and D.M. Chikaraishi. 1987. Regulated expression of the tyrosine hydroxylase gene by epidermal growth factor. Mol. Cell. Biol. 7: 3332-3336.

Lewis, E.J., C.A. Harrington, and D.M. Chikaraishi. 1987. Transcriptional regulation of the tyrosine hydroxylase gene by glucocorticoid and cyclic AMP. Proc. Natl. Acad. Sci. 84: 3550-3554.

Lewis, J.B. and M.B. Matthews. 1980. Control of adenovirus early gene repression in a class of immediate early products. Cell 21: 303-313.

Lewis, S.A. and N.J. Cowan. 1986. Anomalous placement of introns in a number of the intermediate filament multigene family: An evolutionary conundrum. Mol. Cell. Biol. 6: $1529-1534$.

Lillen, L.E., and P. Claude. 1985. Nerve growth factor is a mitogen for cultured chromaffin cells. Nature 317: 632-634.

Lin, R.W., B.C. Varnum, and H.R. Herschman. 1987. Cloning of tetradecanoyl phorbol ester-induced primary response sequences and their expression in density-arrested Swiss 3T3 cells and a TPA non-proliferative variant. Oncogene 1: $263-$ 270.

Lucas, C.A. and H. Thoenen. 1977. Selective induction of glucocorticoids of tyrosine hydroxylase in organ cultures of rat pheochromocytoma. Neuroscience 2: 1095-1101.

Maki, Y., T.J. Bos, C. Davis, M. Starbuck, and P.K. Vogt. 1987. Avian sarcoma virus 17 carries the jun oncogene. Proc. Natl. Acad. Sci. 84: 2848-2852.

Maniatis, T., E. F. Fritsch, and J. Sambrook. 1982. Molecular cloning: A laboratory manual. Cold Spring Harbor Laboratory, Cold Spring Harbor, New York.

Metz, R., I. Gorham, Z. Siegfried, D. Leonard, E. Gizang-Ginsberg, M.A. Thompson, D. Lawe, T. Kouzarides, R. Vosatka, D. Macgregor, S. Jamal, M.E. Greenberg, and E.B. Ziff. 1988. Gene regulation of growth factors. Cold Spring Harbor Symp. Quant. Biol. 53: 727-737.

Milbrandt, J. 1986. Nerve growth factor rapidly induces c-fos mRNA in PC12 rat pheochromocytoma cells. Proc. Natl. Acad. Sci. 83: 4789-4793.

1987. Nerve growth factor rapidly induces a gene which encodes a possible transcription regulatory factor. Science 238: $797-799$.

. 1988. Nerve growth factor induces a gene homologous to the glucocorticoid receptor gene. Neuron 1: 183-188.

Mueller, R.A., H. Thoenen, and J. Axelrod. 1969. Increase in tyrosine hydroxylase activity after reserpine administration. I. Pharmocol. Exp. Ther. 169: 74-79.

Muller, R., R. Bravo, J. Burckhardt, and T. Curran. 1984. Induction of c-fos gene and protein by growth factors precedes activation of c-myc. Nature 312: 716-720.

Nakabeppu, Y., L. Ryder, and D. Nathans. 1988. DNA binding activities of three murine jun proteins: Stimulation by fos. Cell 55: 907-915.

Naujoks, K.W., S. Korsching, H. Rohrer, and H. Thoenen. 1982. Nerve growth factor-mediated induction of tyrosine hydroylase and neurite outgrowth in cultures of bovine adrenal chromaffin cells: Dependence on developmental stage. Dev. Biol. 92: 365-379.

Parysek, L.M., R.L. Chisholm, C.A. Ley, and R.D. Goldman. 1988. A type III intermediate filament gene is expressed in mature neurons. Neuron 1: 395-401.

Passmore, S., R. Elble, and B.K. Tye. 1989. A protein involved in minichromosome maintenance in yeast binds a transcriptional enhancer conserved in eukaryotes. Genes Dev. 3: $921-935$. 
Portier, M.-M., P. Brachet, B. Croizat, and F. Gros. 1984. Regulation of peripherin in mouse neuroblastoma and rat $\mathrm{PCl} 2$ cell lines. Dev. Neurosci. 6: 215-226.

Potter, H., L. Weir, and P. Leder. 1984. Enhancer-dependent expression of human kappa immunoglobulin genes introduced into mouse pre-B lymphocytes by electroporation. Proc. Natl. Acad. Sci. 81: 7161-7165.

Queen, C. and Baltimore, D. 1983. Immunoglobulin gene transcription is activated by downstream sequence elements. Cell 33: $741-748$.

Rapp, U.R., M.D. Goldsborough, G.E. Mark, J. Bonner, J. Groffen, F.H. Reynolds Jr., and J.R. Stephenson. 1985. Structure and biological activity of v-raf, a unique oncogene transduced by a retrovirus. Proc. Nat1. Acad. Sci. 80: 42184222.

Rauscher, F.J., P.J. Vulalas, B.R. Franza, and T. Curran. 1988a. Fos and jun bind cooperatively to the AP-1 site: Reconstitution in vitro. Genes Dev. 2: 1687-1699.

Rauscher, F.J., D.R. Cohen, T. Curran, T.J. Bos, P.K. Vogt, D. Bohmann, R. Tjian, and B.R. Franza Jr. 1988b. Fos-associated protein p39 is the product of the jun-proto-oncogene. Science 240: 1010-1016.

Rauscher III, F.J., L.C. Sambucetti, T. Curran, R.J. Distel, and B.M. Speigelman. 1988c. Common DNA binding site for fos protein complexes and transcription factor AP-1. Cell 52: $471-480$.

Rohrer, H., V. Otten, and H. Thoenen. 1978. On the role of RNA synthesis in the selective induction of tyrosine hydroxylase by nerve growth factor. Brain Res. 159: 436-439.

Ryder, K., L.F. Lau, and D. Nathans. 1988. A gene activated by growth factors is related to the oncogene v-iun. Proc. Natl. Acad. Sci. 85: 1487-1491.

Ryder, K., A. Lanahan, E. Perez-Albuerne, and D. Nathans. 1989. Jun-D: A third member of the jun gene family. Proc. Natl. Acad. Sci. 86: 1500-1503.

Sanger, F., A.R. Coulson, B.G. Barrell, A.J. Smith, and B. Roe. 1980. Cloning in single-stranded bacteriphage as an aid to rapid DNA sequencing. J. Mol. Biol. 143: 161-178.

Sassone-Corsi, P., W.W. Lamph, M. Kamps, and I.M. Verma. 1988a. Fos-associated cellular p39 is related to nuclear transcription factor AP-1. Cell 54: 553-560.

Sassone-Corsi, P., W.W. Lamph, P. Wamsley, and I.M. Verma. $1988 \mathrm{~b}$. Induction of proto-oncogene jun-AP1 by serum and TPA. Nature 334: 629-631.

Sassone-Corsi, P., L.J. Ransone, W.W. Lamph, and I.M. Verma. 1988c. Direct interaction between fos and iun nuclear oncoproteins: Role of the "leucine zipper" domain. Nature 336: 692-695.

Schonthal. A., P. Herrlich, H.J. Rahmsdorf, and H. Ponta. 1988. Requirement for fos gene activation of collagenase by other oncogenes and phorbal esters. Cell 54: 325-334.

Schubert, D., M. LaCorbiere, F.G. Klier, and J.H. Steinbach. 1980. The modulation of neurotransmitters synthesis by steroid hormones and insulin. Brain Res. 190: 67-79.

Setyoma, C., R. Franzio, G. Liau, M. Mudryj, and B. de Crombrugghe. 1986. Transcriptional activation encoded by the v-fos gene. Proc. Natl. Acad. Sci. 83: 3213-3217.

Strauss, F. and A. Varshavsky. 1984. A protein binds to a satellite DNA repeat at three specific sites that would be brought into mutual proximity by DNA folding in the nucleosome. Cell 37: 889-901.

Sukhatme, V.P., S. Kartha, F.G. Toback, R. Taub, R.G. Hoover, and C.H. Tsai-Morris. 1987. A novel early growth response gene rapidly induced by fibroblast, epithelial cell and lymphocyte mitogens. Oncogene Res. 1: 343-355.

Sukhatme, V.P., X.M. Cao, L.C. Chang, C.H. Tsai Morris, D.
Stamenkovich, P.C. Ferreira, D.R. Cohen, S.A. Edwards, T.B. Shows, and T. Curran. 1988. A zinc finger-encoding gene coregulated with c-fos during growth and differentiation, and after cellular depolarization. Cell 53: 37-43.

Tank, A.W., P. Curella, and L. Ham. 1986. Indiction of mRNA for tyrosine hydroxylase by cyclic AMP and glucocorticoids in a rat pheochromocytoma cell line: Evidence for the migration of tyrosine hydroxylase synthesis by multiple mechanisms in cells exposed to elevated levels of both inducing agents. Mol. Pharmacol. 30: 497-503

Thoenen, H. 1970. Induction of tyrosine hydroxylase in peripheral and central adrenergic neurons by cold exposure of rats. Nature 228: 861-862.

Thompson, M.A. and E.B. Ziff. 1989. Structure of the encoding peripherin, an NGF-regulated neuronal specific type III intermnediate filament protein. Neuron 2: 1043-1053.

Tirone, F. and E.M. Shooter. 1989. Early gene regulation by nerve growth factor in PC12 cells: Induction of an interferon-related gene. Proc. Nat1. Acad. Sci. 86: 2088-2092.

Towbin, H., T. Staechlin, and J. Gordon. 1979. Electrophoretic transfer of proteins from polyacrylamide gels in nitrocellulose sheets: Procedure and some applications. Proc. Natl. Acad. Sci. 76: 4350-4354.

Treisman, R. 1985. Transient accumulation of c-fos RNA following serum stimulation requires a conserved 5 ' element and c-fos-3' sequences. Cell 42: 889-902.

Turner, R. and R. Tjian. 1989. Leucine repeats mediate the formation of functional c-fos : c-jun heterodimers. Science 243: $1689-1694$.

Unsicker, K., B. Kirsch, U. Otter, and H. Thoenen. 1978. Nerve growth factor-induced fiber outgrowth from isolated rat adrenal chromaffin cells: Impairment by glucocorticoids. Proc. Natl. Acad. Sci. 75: 3498-3502.

Vosatka, R.J., A. Hermanowski-Vosatka, R. Metz, and E.B. Ziff. 1989. Dynamic interactions of c-fos protein in serum-stimulated 3T3 cells. I. Cell. Physiol. 138: 493-502.

Vulliet, P.R., T.A. Langan, and N. Weiner. 1980. Tyrosine hydroxylase: A substitute of cAMP-dependent protein kinase. Proc. Natl. Acad. Sci. 77: 92-96.

Watson, M.A. and J. Milbrandt. 1989. The NGF I-B gene, a transcriptionally inducible member of the steroid receptor gene superfamily: Genomic structure and expression in rat brain after seizure induction. Mol. Cell. Biol. 9: 4213-4219.

Zerial, M., L. Toschi, R.P. Ryseck, M. Schuermann, R. Muller and R. Bravo. 1989. The product of a novel growth factor activated gene, fos $\mathrm{B}$, interacts with iun proteins enhancing their DNA binding activity. EMBO J. 8: 805-813. 


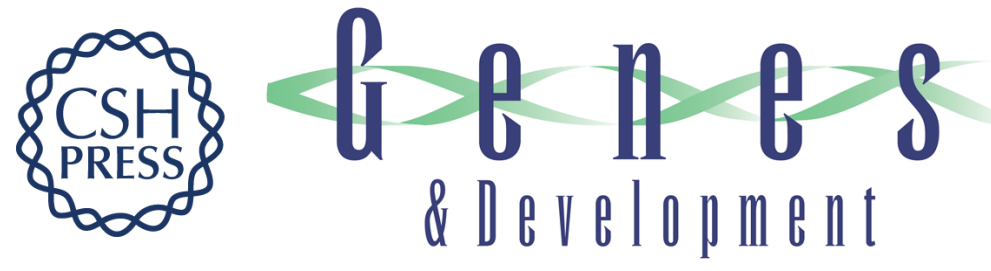

\section{Nerve growth factor regulates tyrosine hydroxylase gene transcription through a nucleoprotein complex that contains c-Fos.}

E Gizang-Ginsberg and E B Ziff

Genes Dev. 1990, 4:

Access the most recent version at doi:10.1101/gad.4.4.477

References This article cites 116 articles, 56 of which can be accessed free at:

http://genesdev.cshlp.org/content/4/4/477.full.html\#ref-list-1

License

Email Alerting

Service

Receive free email alerts when new articles cite this article - sign up in the box at the top right corner of the article or click here.

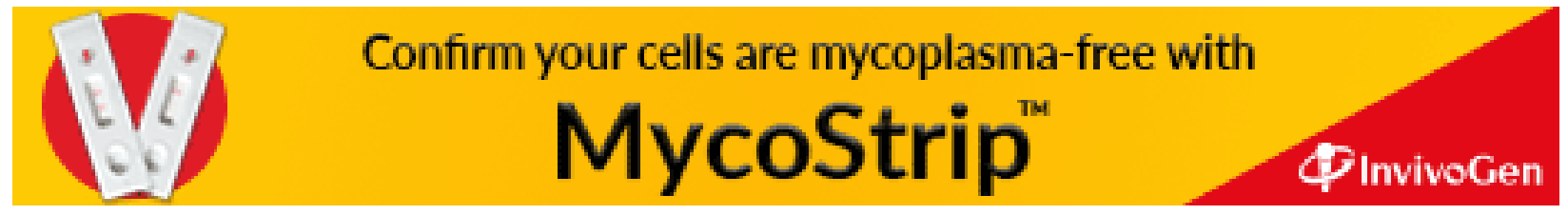

